\title{
CARE International in Afghanistan
}

\section{ASSESSMENT OF EMERGENCY HUMANITARIAN STATUS IN AFGHANISTAN}

The Aftermath of the three years of drought and the U.S. terrorism related air strikes in

Afghanistan

Started on Oct. $7^{\text {th }} 2001$

Emergency Humanitarian Survey Report

Prepared by:

Dr. K. Dawlaty

M\&E Advisor

Eng. Sayed Mohammad Qadery

Data Management Officer

December 2001 


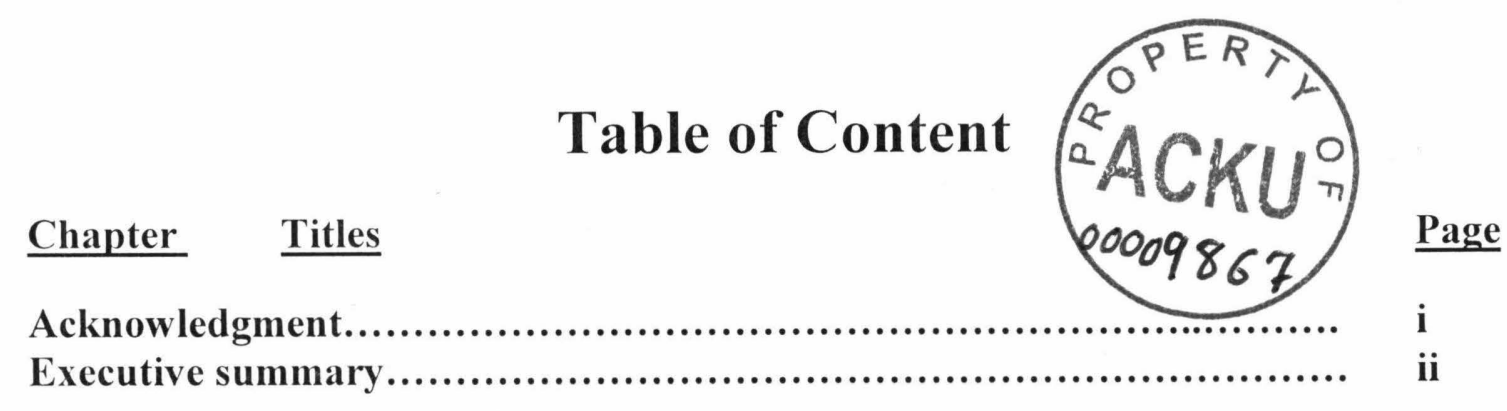

Chapter - 1: Introduction............................................ 1

Chapter - 2: Methodology........................................... 3

\section{Chapter - 3: Survey Findings}

3.1. Population: (Table 1)................................................. 5

3.2. Population vulnerability: (Table 2-a \& 2-b) ............................... 5

3.3. Customary basic diet: (Table 3) ....................................... 7

3.4. Capacity and Assets: (Table 4) ...................................... 8

3.5. Socio-economic comparison of IDPs and residents: (Table 5) ................ 9

3.6. Shelter availability to IDPs and community residence: (Table 6 \& 7) ........ 9

3.7. The Health status, vaccination services and death cases sense displacement: (Table 8-a \& 8-b) ...................................... 10

3.8. IDPs carried out their physical assets and those lost their physical properties: (Table 9).

3.9. Fuel local availability for heating and cooking needs of IDPs \& residents: (Table 10) ............................................. 12

3.10.Food items availability and the prices given: (Table 11)..........

3.11.IDPs location from where they have moved in the sample surveyed districts, and the IDPs households expected to move out from their present location: (Table 12-a \& 12-b).

3.12. Urgent need reported by IDPs and residents households: (Table 13-a \& 13-b).

3.13. Marketing problems related to locally produced cash crops and market price of the main consumer items: (Table 14, 15 \& 16) ....................... 15

3.14. Livestock lost from IDPs and residents villagers: (Table 17)................. 16

3.15. Table (18): Surveyors comments and problems identification on district bases.. 17 


\section{ACKNOLEDGEMENTS}

\section{Those who have participated in this humanitarian emergency survey are:}

Dr. K. Dawlaty

Sayed Mohammad Qadery

Nicolas Plangue

Nashand

Mohd Siddiq

Abdul Kabir Ebrahimi

Sayed Khalid

Mirajuddin

Arsala Jamal

Ghulam Farooq

Mohd Hassan Ahmadzai

Sayed Ibrar

Mohd Samai

Khuaja Jamil

Amir Mohammad

Walid Hakim

Rohullah

Mohd Nadir

Sally Austin

Asif Rahimi

Mohd Yunus

Mohd Akram

Sayed Abdullah

Iqbal Ahmad

Mohd Sayed

Samad

Mahmood Wardak

Dr. Asef

Mohd Jon

Sabahuddin

Bashir Ahmad

Nazir Mohammad

Mahboob

Aziz
Survey Design, data analysis \& report writing

Survey design, data entry, analysis \& report writing

Survey format design

Survey format review

Survey format review

Data entry

Data entry

Data entry

Facilitator \& Report final review

Facilitator \& Report final review

Facilitator

Survey format review \& revision \& Survey Trainer Survey format review $\&$ revision

Survey format review \& revision

Survey format review \& revision

Survey format review \& revision

Survey format review \& revision

Survey location design

Report final review

Report final review

Surveyor

Surveyor

Surveyor

Surveyor

Surveyor

Surveyor

Surveyor

Surveyor

Surveyor

Surveyor

Surveyor

Surveyor

Surveyor

Surveyor 


\section{The Executive Summary}

CARE Afghanistan faced with alarming consequences of 3 years of natural disaster from drought $\left(1999\right.$ - 2001) was unexpectedly confronted with the U.S Sep. $11^{\text {th }}$ terrorism related air strike that further compounded the humanitarian disaster.

These air strikes created a wide scope of complex disaster in cities and in large population centers in Afghanistan. Because of the fear of physical losses and human sufferings, thousands of households became refugees to neighboring countries and a vast number of households became IDPs in safer location inside the country.

The main goal of the current survey was the assessment of the damaging humanitarian status due to the recent U.S. air strikes in targeted areas of Afghanistan together with the impacts of 3 years of continuous natural disaster of drought in the selected geographic locations of the country.

The focal targeted areas selected as a sample for this emergency survey, were the six districts in the four provinces of Kabul, Khost, Ghazni and Paktika (see introduction page 1 for selected districts \& interviews).

Methodology: Because of the urgency of the existing situation and the risks involved conducting this humanitarian status survey, CARE Afghanistan held meeting. According to the meeting with ACBAR and another one with CARE partners, finally in CARE Kabul office it was decided that from 23 selected districts 7 districts should be survey by CARE partners and 16 by CARE program offices. With a quick response CAER partners finished 6 of the 7 districts. The survey of 16 districts to be completed by CARE programs still unfinished.

The processing implemented to the 6 surveyed districts was covering the following process: data entry, tabulation, analysis and report writing. The findings from all of these steps are summarized as a separate chapter "survey findings" within the current report.

\section{Findings:}

The highlights of the statistical findings from the conducted survey in 6 districts are presented on the main point bases in the 18-tables within the text of the report. The related findings within these tables are summarized as follows:

1. Table (1) illustrates that from total estimated population of $(850,820)$ people, $76 \%$ are residents in the six surveyed districts while 24\% are IDPs moved in to the four surveyed districts in Kabul \& Khost provinces. The highest proportion of IDPs $(30 \%)$ and of residents population (70\%) are reported in the urban district of Khairkhana of Kabul. This high proportion of IDPs and residents in this urban district are due to less vulnerability of the district to military targets and air strikes. 
2. From the standpoint of vulnerability (explained in table 2 -a \& 2-b) the populations of the surveyed districts are divided in to three groups for both "IDPs" and "resident" categories. These are 1): most vulnerable 2): vulnerable and 3): non-vulnerable. For "IDPs " and "residents" population in all districts, 93\% are reported "most vulnerable" and "vulnerable" and only 7\% are non-vulnerable. " (see table 2-a \& 2-b)

3. Customary basic diets are listed in table (3). Here it is reported that responses for all diet consumption are higher for "resident population" than those of the "IDPs".

4. "Literacy on gender bases" and "IDPs emergency related skills" is counted as the basic aspects of capacity of households and of their asset bases. Referring to table (4), from all of the (male + female) surveyed people who are literate, $89 \%$ are reported in the large urban district of Khairkhana of Kabul, while $9 \%$ are reported in the rural district of Deh Sabz of that province. The proportion of literate $(\mathrm{M}+\mathrm{F})$ are extremely low $(0.1 \%-1.3 \%)$ in other surveyed districts. For all of the reported seven types of "IDPs skill workers", (table 4), almost all (99.4\%) are living in the large district of Khairkhana of Kabul while only $(0.4 \%)$ are reported in the rural Deh Sabz district of Kabul. In other four districts except few $(0.2 \%)$ in "Tani of Khost" skill workers are not reported at all.

5. In the four of the six survey districts, a total of 40,417 IDPs and 112,669 residents socioeconomic category of (Gov. emp, self-emp, daily worker and others) are reported. In "resident" population, these categories are $2-3$ times more than IDPs. It implies that income-earning securities are higher in residents compare to that of IDPs population.

6. According to the current survey report, on table $(6 \& 7)$, related to temporary shelter only Khairkhana district has reported that $30 \%$ of the IDPs were living in relatives houses while $70 \%$ in rented houses. From the "resident" population $42 \%$ were in their own private houses, $35 \%$ in rented houses, $20 \%$ in relative houses and only $3 \%$ reported using tents. In table (7), shelter availability in 5 of the 6 surveyed districts is confirmed in $40 \%$ of all of the 50 interviews.

7. Related to death cases and vaccination status (table 8-a \& 8-b), it is indicates that from 620 death cases of children in four districts, $52 \%$ have been above 5 , while $48 \%$ were below 5 years of age. The death cases of children in general have been reported the highest $41 \%$ for above 5 years and $38 \%$ for less than 5 years (see table 8 -a). Incidences of diarrhea (table 8-b) are reported $39 \%$ in adults and $61 \%$ in children. Vaccination for children was provided by 5 -health organization (WHO, Unicef, SCA, NPO and Ibn-e-Sina) for coverage see 3.7 page 10.

8. Table (10) presents the availability and the prices of fuel for cooking and heating purpose. The range of prices of diesel and kerosene are reported (19-25 Rs./ lit) in $3-4$ surveyed districts. The range of prices of collected bush is given in 3 districts at Rs. 1.5 $13 / 7 \mathrm{~kg}$. Price of charcoal as a traditional heating \& cooking fuel is reported only in Khairkhana district of Kabul.

9. Except in the district of Deh Sabz in Kabul and in Ismail Khail of Khost, food items availability are reported in all of the districts by a limited No. of responses. In table (11) average prices Rs./ $\mathrm{kg}$ of food items are reported 54.4, 35.5, 26, 18, 13.2 and 12 for cooking oil, beans, mong beans, rice wheat flour and for wheat respectively (see table 11).

\footnotetext{
^For more elaboration of the concepts "vulnerability" see footnote table 2-b, annex I, and item 3 of chapter 3.
} 
10. The locations from where IDPs have been displaced from and the date of arrival of IDPs with reasons for displacement are summarized in (table 12-a). Here their locations of origin are Kabul, Khost, Qataghan and Shamali. The main reasons for moving out from their origin area are U.S strikes, war in general, drought, un-security and poverty. The date for their displacement is reported from 11/09/2001 up to 10/10/2001. *

11. In table (12-b), the responses related to moving out of IDPs, from the 35 responses, $54 \%$ have indicated "don't know" $37 \%$ have said will not move out at all, while $9 \%$ have said "yes" they may moved out to Pakistan or to their homes.

12. The urgent needs to make IDPs and residents HHs shelter suitable to live is presented in (table 13-a \& 13-b). Here for "IDPs" and "residents" winterization items are the most important needs. Door, windows and shelter are the next priority needs.

13. Marketing problems in locally produced cash crops are the high transport cost (14\% of responses), storage problems ( $8 \%$ responses), lower local price $(6 \%$ of responses) refer to the data (table 15).

14. The local prices of cash crops (cash product) are highest for apple (Rs. $32.7 / \mathrm{kg}$ ) next to that are potatoes (Rs. 9.2/ kg) and following to those are carrots and onions, (Rs. 6.3/ kg and Rs. 4.6) respectively (see table 14).

On market prices of the main consumers items the prices are reported in (table 16). Here the "average prices" of the consumer items with their "standard deviation" as an indicator of variation are reported on detailed bases.

The highest average prices Rs. $71 / \mathrm{kg}$ and Rs. $57 / \mathrm{kg}$ are reported for mutton and beef respectively. The next highest average prices are Rs. $50 / \mathrm{kg}$ and $\mathrm{Rs} .37 / \mathrm{kg}$ for cooking oil and beans.

Mong beans and rice are following to these food item prices. The lowest average price is reported Rs. 12/ kg for wheat flour.

As a measure of variation of prices, the statistical coefficient of variation (standard deviation) is illustrating the size of variation of prices existing on district bases for each commodity within the surveyed districts.

15. Livestock loses from IDPs and residents populations are reported on (\%) bases by the respondents. In total responses loses of livestock on average base from residents are more in residents population than those of IDPs. This higher loses can be attributed to severe drought situation on animal husbandry activities of resident population.

\footnotetext{
* Related to drought, the started date of displacement is 01/01/1998.
} 


\section{CHAPTER - 1 \\ INTRODUCTION}

The U.S. terrorism related air strikes on Afghanistan began on October $7^{\text {th }} 2001$. These strikes created a complex disaster linked to socio-economic, political and warfare situation. The air strikes, though specifically targeted, created a wide scale disaster in cities and large population centers in the country. Because of fear of physical losses and human suffering, thousands of people (households) became refugees to neighboring countries. A vast number of households who couldn't stay in the big cities and risky smaller towns and couldn't get their families outside the country became IDPs to safer locations inside the country.

For assistance in programming of making emergency support to CARE Afghanistan launched a quick humanitarian support survey, for the assessment of the situation of IDPs who moved to safer places in rural and urban areas.

The selected IDPs areas covered, as a sample survey through key informant and group meeting with no separate meeting with IDPs for this disaster needs assessment, were in the following provinces and districts.

\begin{tabular}{llc} 
Province & District & Interviews \\
\cline { 3 - 3 } Kabul & & Deh Sabz \\
& Khair Khana & 8 \\
\multirow{2}{*}{ Khost } & Tani & 8 \\
& Ismail Khail & 8 \\
Ghazni & Ab-band & 8 \\
Paktika & Jani Khail & 8 \\
\hline & For all districts $=$ & $\mathbf{5 0}$
\end{tabular}

In order to include the "drought effected" areas and the vulnerability aspects of population, beside the IDPs, the Residents (non-IDPs) in the surveyed areas were also included in selected sections of the current survey format (see the form, attached in annex I).

The main goal of the current survey has been an assessment of the damaging impacts of U.S. air strikes in targeted areas in Afghanistan. Parallel to that, the assessment of negative impacts of "continuous three years of drought" in selected sample districts of the four central \& south provinces of Kabul, Khost, Ghazni and Paktika was also covered. 
The main objectives targeted through the current survey of the six vulnerable sample districts are as follows:

1. To estimate the IDPs and residents population size in the targeted surveyed districts.

2. To find the "IDPs" and the local "Residents population" vulnerability status in the surveyed areas.

3. To find the socio-economic status of IDPs and the drought affected residents in the surveyed areas.

4. To find the health status, death and the status of services of vaccination and the incidences of diarrhea, in IDPs and residents population.

5. To specify the physical assets and the human capacity of only IDPs in the surveyed areas and the loss of assets through displacement in the disaster situation.

6. To find the availability of fuel, food and shelter needs in the surveyed areas.

7. To find the loss of livestock from IDPs and residents.

8. To find the assts carried out and personal properties lost by IDPs.

9. To find the temporary shelter availability and rate of rent paid by IDPs.

10. Cash crops production, marketing and main local prices 


\section{CHAPTER - 2 \\ METHODOLOGY}

A "Survey Format" was prepared. This format was covering the assessment of humanitarian status following the stress of three years of continuous natural disaster of drought in central and south central Afghanistan and the human made "disaster" of U.S. air strikes to the targeted locations in Afghanistan. This emergency survey tool (Annex I)was drafted in CARE Afghanistan main office in Peshawar in late October.

Beside some deletions and few additions of some new questions, the review committee of the survey set the implementation of this "emergency survey" on the following bases:

1. The geographic areas to be covered were chosen as those areas, prior to the U.S. air strike areas in Afghanistan, some of the CARE partner based areas and those of the areas where there were no NGOs involved at all see (table i). Non-NGOs areas were included to frame a disaster situation in typical normal communities.

2. For sharing suggestions on choosing sample areas the issue of area to be selected for the current humanitarian emergency survey has been discussed in an ACBAR meeting in Kabul. Later to this CARE Afghanistan partner organization, some other NGOs and CARE Afghanistan program, focused on this aspect of the survey. Finally a CARE office meeting in Kabul discussed to select 23 districts from which 7 districts were to be surveyed by CARE partners and 16 by the CARE programs in selected districts for this emergency purpose. Partners first completed the survey of 6 selected districts; the $7^{\text {th }}$ district (Nawa in Ghazni province) remained late and was not included in the current analysis. From the 23 districts the 16 districts selected to be survey by CARE office has not been completed yet, thus they are not included in this report.

Table (i): The emergency surveyed areas covered by other NGOs Program and areas with no NGOs programs.

\begin{tabular}{|c|c|c|c|c|c|c|c|c|c|c|}
\hline \multicolumn{2}{|c|}{ Survey localities } & \multicolumn{2}{|c|}{ NGOs \& Activities } & \multicolumn{2}{|c|}{ NGOs \& Activities } & \multicolumn{2}{|c|}{ NGOs \& Activities } & \multicolumn{2}{|c|}{ NGOs \& Activities } & \multirow{2}{*}{$\begin{array}{l}\text { Total } \\
\text { NGOs }\end{array}$} \\
\hline Province & District & Name & Activity & Name & Activity & Name & Activity & Name & Activity & \\
\hline \multirow{2}{*}{ Kabul } & Deh Sabz & APA & Shelter & ARDO & Shelter & WRC & Food act & WROR & Shelter & 4 \\
\hline & Khair Khana & * & & * & & * & & $*$ & & \\
\hline \multirow[t]{2}{*}{ Khost } & Tani & SCA & $\begin{array}{c}\text { Health } \\
\text { Education }\end{array}$ & & & & & & & 1 \\
\hline & Ismail Khel & $*$ & & $*$ & & $*$ & & $*$ & & \\
\hline Ghazni & Aab Band & $*$ & & $*$ & & $*$ & & * & & \\
\hline Paktika & Jani Khel & * & & * & & * & & $*$ & & \\
\hline \multicolumn{2}{|c|}{ Total Number } & 2 & & 1 & & 1 & & 1 & & 5 \\
\hline
\end{tabular}

* Note: Areas where NGOs programs were not reported 
3. The sources that have been used for providing the required information are mainly 20 "community group meetings" and 30 "key informants group meeting". The summary of these interviews on district bases is briefed in the following table.

Table (ii): The summary of types of interviews applied:

\begin{tabular}{|c|c|c|c|c|}
\hline \multicolumn{2}{|c|}{ Survey localities } & \multirow{2}{*}{$\begin{array}{c}\text { Interviews } \\
\text { No. }\end{array}$} & \multirow{2}{*}{$\begin{array}{c}\text { Key informant } \\
\text { Response } \\
\end{array}$} & \multirow{2}{*}{$\begin{array}{c}\text { Group meeting } \\
\text { Response } \\
\end{array}$} \\
\hline Province & District & & & \\
\hline \multirow{2}{*}{ Kabul } & Deh Sabz & 10 & 10 & \\
\hline & Khair Khana & 8 & 4 & 4 \\
\hline \multirow{2}{*}{ Khost } & Tani & 8 & 4 & 4 \\
\hline & Ismail Khel & 8 & 5 & 3 \\
\hline Ghazni & Aab Band & 8 & 3 & 5 \\
\hline Paktika & Jani Khel & 8 & 4 & 4 \\
\hline \multicolumn{2}{|r|}{ Total } & 50 & 30 & 20 \\
\hline
\end{tabular}

4. The surveyors', 14 individuals were all the members of the CARE partner organizations, whose name and designation are briefed in table (iii).

Table (iii): CARE partner members participated as surveyors.

\begin{tabular}{|c|l||l|l|}
\hline S/ No. & Surveyors & Organization & \multicolumn{1}{|c|}{ Designation } \\
\hline \hline 1 & Eng. Mohd Yunus & ACRU & Site Engineer \\
\hline 2 & Haji Mohd Akram & ACRU & Finance Officer \\
\hline 3 & Dr. Sayed Abdullah & AHDAA & Member \\
\hline 4 & Eng. Iqbal Ahmad & AHDAA & Program Manager \\
\hline 5 & Eng. Mohd Sayed & AHDAA & Site Engineer \\
\hline 6 & Eng. Samad & AHDAA & Responsible of \\
\hline 7 & Mahmood Wardak & APWO & Kabul Office Manager of \\
\hline 8 & Dr. Asef & BCURA & Dam \& Canal Coordinator \\
\hline 9 & Eng. Mohd Jon & BCURA & Finance Officer \\
\hline 10 & Sabahuddin & BCURA & Regional Manager \\
\hline 11 & Eng. Bashir Ahmad & PDA & Site Engineer \\
\hline 12 & Eng. Nazir Mohd & PDA & Site Engineer \\
\hline 13 & Mahboob & ADEB & Site Engineer \\
\hline 14 & Aziz & ADEB & Administrator \\
\hline
\end{tabular}

On district and NGO (organizational) bases the surveyors' participations are illustrated in table (iv).

Table (iv): The number of surveyors from the participating "CARE partners".

\begin{tabular}{|l|l||c|c|c|c|c|c|}
\hline \multicolumn{2}{|l||}{ Survey localities } & \multicolumn{5}{c|}{ CARE Partners Organization surveyors (No.) } \\
\hline Province & District & BCURA & AHDAA & APWO & ACRU & ADEB & PDA \\
\hline \hline \multirow{2}{*}{ Kabul } & Deh Sabz & & & & & & 2 \\
\cline { 2 - 8 } & Khair Khana & & 4 & & & & \\
\hline \multirow{2}{*}{ Khost } & Tani & & & 1 & & & \\
\cline { 2 - 8 } & Ismail Khel & & & & & 2 & \\
\hline Ghazni & Aab Band & 3 & & & & & \\
\hline Paktika & Jani Khel & & & & 2 & & \\
\hline \hline \multicolumn{2}{|l|}{ Total Number } & $\mathbf{3}$ & $\mathbf{4}$ & $\mathbf{1}$ & $\mathbf{2}$ & $\mathbf{2}$ & $\mathbf{2}$ \\
\hline
\end{tabular}




\section{CHAPTER - 3 \\ SURVEY FINDINGS}

For IDPs and the residential population the following humanitarian aspects in the "six selected areas" have been surveyed. The analytical tables from the survey findings are arranged and discussed within the text of the report as follows:

\subsection{Population: (Table I)}

From the total estimated population $(850,820)$ people in the 6 surveyed districts, almost one quarter (24\%) have been reported as IDPs, while $76 \%$ are reported as the residents of all of the surveyed districts (see table 1). Here as the table shows, IDP populations are not reported in two districts of "Aband" and "Jani Khail" of Ghazni and Paktika provinces respectively. In the large district of Khairkhana the highest proportion $(30 \%)$ of population are IDPs while the remaining $70 \%$ are residents. On total population bases, $75 \%$ of surveyed populations are located in this large district of Kabul. This large population proportion of IDPs (30\%) as indicated in table (1) due to the fact that this large area of Kabul city has less vulnerability from the standpoint of military targets.

Table (1): Surveyed areas \& population size on district basis:

\begin{tabular}{|c|c|c|c|c|c|c|}
\hline \multirow{2}{*}{\multicolumn{2}{|c|}{ Survey localities }} & \multirow{3}{*}{$\begin{array}{c}\text { IDP } \\
\text { Population } \\
\text { No. } \\
\end{array}$} & \multirow{3}{*}{$\begin{array}{c}\text { Resident } \\
\text { Population } \\
\text { No. }\end{array}$} & \multirow{3}{*}{$\begin{array}{c}\begin{array}{c}\text { Total } \\
\text { Population }\end{array} \\
\text { No } \\
\end{array}$} & \multicolumn{2}{|c|}{ Population distribution } \\
\hline & & & & & \multirow{2}{*}{$\begin{array}{c}\text { IDPs } \\
\%\end{array}$} & \multirow{2}{*}{$\begin{array}{c}\text { Resident } \\
\%\end{array}$} \\
\hline Province & District & & & & & \\
\hline \multirow{2}{*}{ Kabul } & Deh Sabz & 4295 & 39900 & 44195 & 10 & 90 \\
\hline & Khair Khana & 193316 & 443605 & 636921 & 30 & 70 \\
\hline \multirow{2}{*}{ Khost } & Tani & 7150 & 67475 & 74625 & 10 & 90 \\
\hline & Ismail Khel & 3355 & 45019 & 48374 & 7 & 93 \\
\hline Ghazni & Aab Band & 0 & 8020 & 8020 & 0 & 100 \\
\hline Paktika & Jani Khel & 0 & 38685 & 38685 & 0 & 100 \\
\hline \multicolumn{2}{|c|}{ Total population } & 208116 & 642704 & 850820 & & \\
\hline \multicolumn{2}{|c|}{$\%$ IDPs \& residents } & & & & 24 & 76 \\
\hline
\end{tabular}

\subsection{Population vulnerability: (Table $2-a \& 2-b)$}

In all of the surveyed districts, "population vulnerability" status were explored for finding the scope/ scale of capacity of tolerating risks by the household of the communities through this rapid survey. The higher the tolerance of risks ${ }^{\star}$ in a household, the smaller will be the level of vulnerability in that household. For this purpose the population of "IDPs" and "Residents" were divided in to "most vulnerable", "vulnerable" and "non-vulnerable" categories (see table 2-a \& 2-b) and the footnote for the definition of the three vulnerability concepts."

From the IDPs total population "199,655" people, 1855,99 (93\%) were reported "most vulnerable" and "vulnerable" while only 14056 people (7\%) were reported "non-vulnerable". From the resident total population, $(512,322)$ people, the same proportion 476,831 people $(93 \%)$ are shown "most

^ Risks imply the situation of shortage of food and non-food items and limitation of job opportunities and sources of income.

* 1. Most Vulnerable: Very old (shikh fani), widow, disable, orphans or who do not have anybody to work and also without any means of income.

2. Vulnerable: One who does not have money for his/ her family daily expenses for food and does not have the opportunity to work. And those who are deeply affected by drought.

3. Non-Vulnerable: One who can live without external support. 
vulnerable" and "vulnerable" while the remaining 7\% are non-vulnerable. On district bases, resident population in "Khairkhana" of Kabul has the highest vulnerability proportion while in "Tani" district of Khost the IDPs are highly vulnerable. These similar high vulnerability proportions in IDPs and residents population in the related districts are highly alarming indicators of the worst situation of humanitarian needs in the surveyed districts (see table 2-a \& 2-b) and the footnote on page 5 .

On comparative bases, the proportion of "most vulnerable" and "vulnerable" IDPs population are the highest (99\%) in the district of "Tani" of Khost (table 2-a). While in resident population, the proportion of "most vulnerable" and "vulnerable" population is reported slightly less (96\%) in Khairkhana of Kabul (table 2-b). This comparative similarity in vulnerability between IDPs and resident population is indicating the requirement of support of survival needs for the residents of Khairkhana district of Kabul, and for the IDPs in "Tani" of Khost province.

Table (2-a): IDPs population vulnerability * Status

\begin{tabular}{|c|c|c|c|c|c|c|c|c|c|c|c|c|c|c|c|}
\hline \multirow{2}{*}{\multicolumn{2}{|c|}{ Survey localities }} & \multicolumn{14}{|c|}{ IDP } \\
\hline & & \multicolumn{6}{|c|}{ Most vulnerable } & \multicolumn{2}{|c|}{ Vulnerable } & \multicolumn{2}{|c|}{ Total } & \multicolumn{2}{|c|}{ Non-vulnerable } & \multirow{2}{*}{\multicolumn{2}{|c|}{ Grand Total }} \\
\hline \multirow{2}{*}{ Province } & \multirow{2}{*}{ District } & \multicolumn{2}{|c|}{ Widows } & \multicolumn{2}{|c|}{ Shikh Fani } & \multicolumn{2}{|c|}{ Disabled } & \multirow{2}{*}{ (No.) } & \multirow{2}{*}{$\%$} & \multirow{2}{*}{ (No.) } & \multirow{2}{*}{$\%$} & \multirow{2}{*}{ (No.) } & \multirow{2}{*}{$\%$} & & \\
\hline & & (No.) & $\%$ & (No.) & $\%$ & (No.) & $\%$ & & & & & & & (No.) & $\%$ \\
\hline \multirow{2}{*}{ Kabul } & Deh Sabz & 0 & 0 & 0 & 0 & 0 & 0 & 0 & 0 & 0 & 0.0 & 0 & 0 & 0 & 0 \\
\hline & Khair Khana & 193 & 6 & 136 & 8 & 41 & 3 & 435 & 0 & 805 & 0.4 & 13947 & 99 & 14752 & 7 \\
\hline \multirow{2}{*}{ Khust } & Tani & 2696 & 88 & 1538 & 88 & 1238 & 96 & 178322 & 99 & 183794 & 99.0 & 109 & 1 & 183903 & 92 \\
\hline & Ismail Khel & 144 & 5 & 13 & 1 & 1 & 0 & 297 & 0 & 455 & 0.2 & 0 & 0 & 455 & 0 \\
\hline Ghazni & Aab Band & 32 & 1 & 52 & 3 & 15 & 1 & 446 & 0 & 545 & 0.3 & 0 & 0 & 545 & 0 \\
\hline Paktika & Jani Khel & 0 & 0 & 0 & 0 & 0 & 0 & 0 & 0 & 0 & 0.0 & 0 & 0 & 0 & 0 \\
\hline & Total & 3065 & 100 & 1739 & 100 & 1295 & 100 & 179500 & 100 & 185599 & 100 & 14056 & 100 & 199655 & 100 \\
\hline
\end{tabular}

Table (2-b): Residents population vulnerability Status

\begin{tabular}{|c|c|c|c|c|c|c|c|c|c|c|c|c|c|c|c|}
\hline \multirow{2}{*}{\multicolumn{2}{|c|}{ Survey localities }} & \multicolumn{14}{|c|}{ Residents } \\
\hline & & \multicolumn{6}{|c|}{ Most vulnerable } & \multicolumn{2}{|c|}{ Vulnerable } & \multicolumn{2}{|c|}{ Total } & \multicolumn{2}{|c|}{ Non-vulnerable } & \multirow{2}{*}{\multicolumn{2}{|c|}{ Grand Total }} \\
\hline \multirow{2}{*}{ Province } & \multirow{2}{*}{ District } & \multicolumn{2}{|c|}{ Widows } & \multicolumn{2}{|c|}{ Shikh Fani } & \multicolumn{2}{|c|}{ Disabled } & \multirow{2}{*}{ (No.) } & \multirow{2}{*}{$\%$} & \multirow{2}{*}{ (No.) } & \multirow{2}{*}{$\%$} & \multirow{2}{*}{ (No.) } & \multirow{2}{*}{$\%$} & & \\
\hline & & (No.) & $\%$ & (No.) & $\%$ & (No.) & $\%$ & & & & & & & (No.) & $\%$ \\
\hline \multirow[t]{2}{*}{ Kabul } & Deh Sabz & 897 & 11 & 761 & 16 & 343 & 8 & 5420 & 1 & 7421 & 2 & 9 & 0 & 7430 & 1 \\
\hline & Khair Khana & 6279 & 78 & 3012 & 63 & 2877 & 67 & 446080 & 97 & 458248 & 96 & 32551 & 92 & 490799 & 96 \\
\hline \multirow[t]{2}{*}{ Khust } & Tani & 362 & 5 & 460 & 10 & 340 & 8 & 3600 & 1 & 4762 & 1 & 675 & 2 & 5437 & 1 \\
\hline & Ismail Khel & 294 & 4 & 242 & 5 & 210 & 5 & 1571 & 0 & 2317 & 0 & 2006 & 6 & 4323 & 1 \\
\hline Ghazni & Aab Band & 77 & 1 & 55 & 1 & 60 & 1 & 777 & 0 & 969 & 0 & 217 & 1 & 1186 & 0 \\
\hline Paktika & Jani Khel & 114 & 1 & 260 & 5 & 485 & 11 & 2255 & 0 & 3114 & 1 & 33 & 0 & 3147 & 1 \\
\hline \multicolumn{2}{|c|}{ Total } & 8023 & 100 & 4790 & 100 & 4315 & 100 & 459703 & 100 & 476831 & 100 & 35491 & 100 & 512322 & 100 \\
\hline
\end{tabular}




\subsection{Customary basic diet: (Table 3)}

A list of customary basic diets of the villagers is illustrated for IDPs and resident villagers in (table 3 ). Here for the IDPs and for the resident's responses are reported for the use of each one of the 8 indicated items in the surveyed districts. The total responses for consumption of each one of the 8 items (see bottom row of table 3) are higher for residents compared to the "IDPs" households. This comparison of more responses for diet consumption by residents than IDPs are also illustrated separately in a table as follows:

Expected and actual reporting of customary basic diet:

\begin{tabular}{|c|c|c|c|c|c|c|}
\hline \multirow[t]{2}{*}{ Food Items } & \multicolumn{2}{|c|}{$\begin{array}{l}\text { Expected total } \\
\text { reporting on each } \\
\text { item from } 6 \text { districts }\end{array}$} & \multicolumn{2}{|c|}{$\begin{array}{l}\text { Actual reporting on "IDPs" } \\
\text { customary basic diets }\end{array}$} & \multicolumn{2}{|c|}{$\begin{array}{l}\text { Actual reporting on } \\
\text { "residents" customary } \\
\text { basic diets }\end{array}$} \\
\hline & No. & $\%$ & No. & $\%$ & No. & $\%$ \\
\hline Bread & 50 & 100 & 35 & 70 & 50 & 100 \\
\hline Vegetable & 50 & 100 & 11 & 22 & 26 & 52 \\
\hline Rice & 50 & 100 & 23 & 46 & 41 & 82 \\
\hline Gee & 50 & 100 & 17 & 34 & 32 & 64 \\
\hline Tea & 50 & 100 & 31 & 62 & 50 & 100 \\
\hline Onion & 50 & 100 & 16 & 32 & 32 & 64 \\
\hline Sugar & 50 & 100 & 17 & 34 & 24 & 48 \\
\hline Meat & 50 & 100 & 0 & 0 & 7 & 14 \\
\hline
\end{tabular}

Looking at the customary diet reporting, bread is a widely reported diet item in both "IDPs" and "resident" villagers. Tea as a component of the Afghan customary diet is second in ranking of reporting in IDPs, but the highest in resident household, which ranks parallel with bread. Tea and bread is a typical diet of poor people in Afghanistan.

Meat as a very high quality customary diet is not reported as consumed by the IDPs at all. In resident villagers, only 14\% reported from Ismail Khail district of Khost (table 3).

Table (3): Customary basic diet of the villagers:

\begin{tabular}{|c|c|c|c|c|c|c|c|c|c|c|c|c|c|c|c|c|c|}
\hline \multicolumn{2}{|c|}{ Survey localities } & \multicolumn{8}{|c|}{ Responses for IDP } & \multicolumn{8}{|c|}{ Responses for residents } \\
\hline Province & District & Bread & Veget. & Rice & Gee & Tea & Onion & Sugar & Meat & Bread & Veget. & Rice & Gee & Tea & Onion & Sugar & Meat \\
\hline \multirow{2}{*}{ Kabul } & Deh Sabz & 10 & 2 & 7 & & 6 & & & & 10 & 1 & 9 & & 10 & & & \\
\hline & Khair Khana & 8 & 8 & 8 & 8 & 8 & 8 & 8 & & 8 & 8 & 8 & 8 & 8 & 8 & 8 & \\
\hline \multirow{2}{*}{ Khost } & Tani & 8 & 0 & 8 & 8 & 8 & 8 & & & 8 & & 8 & 8 & 8 & 8 & & \\
\hline & Ismail Khel & 8 & 0 & & & 8 & & 8 & & 8 & 8 & 8 & 8 & 8 & 8 & 8 & 7 \\
\hline Ghazni & Aab Band & 1 & 1 & & 1 & 1 & & 1 & & 8 & 8 & & & 8 & & 8 & \\
\hline Paktika & Jani Khel & & & & & & & & & 8 & 1 & 8 & 8 & 8 & 8 & & \\
\hline \multicolumn{2}{|c|}{ No. of response } & 35 & 11 & 23 & 17 & 31 & 16 & 17 & 0 & 50 & 26 & 41 & 32 & 50 & 32 & 24 & 7 \\
\hline
\end{tabular}




\subsection{Capacity and Assets: (Table 4)}

The assessment focused on the level of literacy and on IDPs emergency related skills are reflecting the status of capacity and asset bases of the war and drought stricken people in the surveyed districts.

The outcomes of these two aspects (literacy and asset) are illustrated in (table 4). In this table, in the urban district of "Khairkhana" as a very large district of Kabul, 89\% of total (female + male) literate population $(92,875)$ are reported, while in the rural district of "Deh Sabz" close to north east of Kabul city, only about 9\% of "male + female" literates are reported. The numbers of literate distribution (male + female) reported are very low $(0.1 \%-1.3 \%)$ in the other four surveyed districts (see table 4 under literate people).

Skilled workers are not reported in IDPs of Ismail Khail of Khost, Aband of Ghazni and Jani Khail of Paktika. In the urban district of Khairkhana of Kabul from 101,799 IDPs 99.4\% laborers and government employees are the basic capacity and asset base of "IDPs". Very few skilled workers [(424) individuals] are reported as carpenters, drivers, masons and tailors in rural area of Deh Sabz of Kabul. In Tani district of Khost just 195 skilled workers are reported as IDPs, in that district. (see table 4)

Literacy rate $(\%)$ on total surveyed population bases is illustrated in (table 4-b). Here Khairkhana has the highest rate of literacy (10\%), Deh Sabz (1\%) and other districts are less than 1\%.

Table (4): Literate population distribution on district bases in the communities/villages:

\begin{tabular}{|c|c|c|c|c|c|c|c|c|c|c|c|c|c|c|c|c|}
\hline \multirow{2}{*}{\multicolumn{2}{|c|}{ Survey localities }} & \multicolumn{6}{|c|}{ Literate People } & \multicolumn{7}{|c|}{ IDP's Emergency related skills* } & \multicolumn{2}{|c|}{ Total } \\
\hline & & \multicolumn{2}{|c|}{ Male } & \multicolumn{2}{|c|}{ Female } & \multicolumn{2}{|c|}{ Total $(M+F)$} & \multirow{2}{*}{\begin{tabular}{|c|} 
Carpe \\
No. \\
\end{tabular}} & \multirow{2}{*}{$\begin{array}{c}\text { Mech. } \\
\text { No. }\end{array}$} & \multirow{2}{*}{\begin{tabular}{|c|} 
Driver \\
No \\
\end{tabular}} & \multirow{2}{*}{$\begin{array}{c}\text { Masons } \\
\text { No. }\end{array}$} & \multirow{2}{*}{$\begin{array}{c}\text { Tailor } \\
\text { No } \\
\end{array}$} & \multirow{2}{*}{$\begin{array}{c}\text { Laborer } \\
\text { No } \\
\end{array}$} & \multirow{2}{*}{\begin{tabular}{|c|} 
Gov. \\
Empl. \\
No. \\
\end{tabular}} & \multirow[t]{2}{*}{ No. } & \multirow[t]{2}{*}{$\%$} \\
\hline Province & District & No. & $\%$ & No. & $\%$ & No. & $\%$ & & & & & & & & & \\
\hline \multirow{2}{*}{ Kabul } & Deh Sabz & 6807 & 10.7 & 1207 & 4.1 & 8014 & 8.6 & 101 & & 60 & 188 & 75 & & & 424 & 0.4 \\
\hline & Khair Khana & 54449 & 85.5 & 27977 & 95.7 & 82426 & 88.7 & & & & & & 90804 & 10995 & 101799 & 99.4 \\
\hline \multirow{2}{*}{ Khost } & Tani & 343 & 0.5 & 15 & 0.1 & 358 & 0.4 & 70 & 15 & & 75 & 35 & & & 195 & 0.2 \\
\hline & Ismail Khel & 1184 & 1.9 & 20 & 0.1 & 1204 & 1.3 & & & & & & & & 0 & 0.0 \\
\hline Ghazni & Aab Band & 96 & 0.2 & 0 & 0.0 & 96 & 0.1 & & & & & & & & 0 & 0.0 \\
\hline Paktika & Jani Khel & 777 & 1.2 & 0 & 0.0 & 777 & 0.8 & & & & & & & & 0 & 0.0 \\
\hline & Total & 63656 & & 29219 & & 92875 & & 171 & 15 & 60 & 263 & 110 & 90804 & 10995 & 102418 & \\
\hline & $\%$ & & 100 & & 100 & & 100 & 0.17 & 0.01 & 0.06 & 0.26 & 0.11 & 88.66 & 10.74 & & 100.0 \\
\hline
\end{tabular}

Table (4-b): Literacy rate on total population bases on the surveyed districts

\begin{tabular}{|c|c|c|c|c|}
\hline \multicolumn{2}{|c|}{ Survey localities } & \multicolumn{3}{|c|}{ Population } \\
\hline Province & District & Literate & Total & $\%$ Literate \\
\hline \multirow{2}{*}{ Kabul } & Deh Sabz & 44195 & 8014 & 0.94 \\
\hline & Khair Khana & 636921 & 82426 & 9.69 \\
\hline \multirow{2}{*}{ Khost } & Tani & 74625 & 358 & 0.04 \\
\hline & Ismail Khel & 48374 & 1204 & 0.14 \\
\hline Ghazni & Aab Band & 8020 & 96 & 0.01 \\
\hline Paktika & Jani Khel & 38685 & 777 & 0.09 \\
\hline \multicolumn{2}{|c|}{ Total } & 850820 & 92875 & 10.92 \\
\hline
\end{tabular}




\subsection{Socio-economic comparison of IDPs and residents: (Table 5)}

In (table 5), a total population of $(40,417)$ IDPs, and $(112,669)$ residents are reported in four socioeconomic categories (Gov. emp. Self- emp. Daily workers and others)

The IDPs socio-economic group of population in all of the districts $(40,417)$ is almost $1 / 3(26 \%)$ of the resident population 112,669 (74\%). (see the related totals in table 5). This comparison implies that socio-economic security of "IDPs" have been reported in much lower status than those of the "resident" population.

Table (5): Socio-economics status of IDPs and victimized residents:

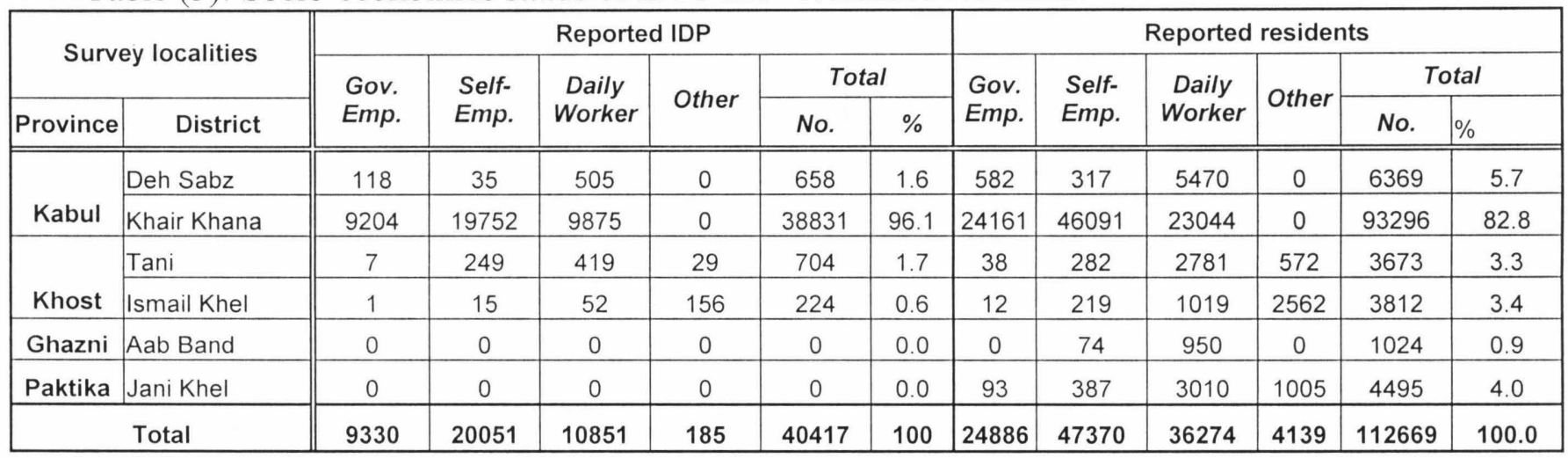

\subsection{Shelter availability to IDPs and community residence: (Table $6 \& 7$ )}

Looking at (table 6) on types of temporary shelters used by IDPs, only one district of "Khairkhana" in urban area of Kabul has provided information. In this district it was reported that $30 \%$ of IDPs HHs are living in relative houses while $70 \%$ of them are living in rental houses.

The resident of "Khairkhana", (table 6), $42 \%$ of HHs were in their own private houses, $35 \%$ in rented houses*, $20 \%$ were reported being in their relative houses while only $3 \%$ (vulnerable) were indicated using tent as their shelter. In resident section of Khairkhana this shelter aspect of the disaster-affected population implies that resident section had a wider level of shelter choices compared to the IDPs population where there are only the two choices of renting or relative houses.

As the alternative choices for residency status of shelter are broader compared to that of IDPs. (Table 7) confirms shelter availability in 5 of the 6 surveyed districts by $40 \%$ of the interviews (responses). The information of rate of shelter rent (only given in Khairkhana) is Rs. 2000/ month.

\footnotetext{
* The reasons that the residents HHs moved out to relative or, rented hoses or in to tents has been due to the existing of tangible or non-tangible risks in the locations of their own houses.
} 
Table (6): Types of temporary shelters used by IDPs/residents:

\begin{tabular}{|c|c|c|c|c|c|c|c|c|c|c|c|c|c|}
\hline \multirow{2}{*}{\multicolumn{2}{|c|}{ Survey localities }} & \multicolumn{6}{|c|}{ IDPs Temporary Shelter } & \multicolumn{6}{|c|}{ Residents Temporary Shelter } \\
\hline & & \multirow{2}{*}{\begin{tabular}{|c|}
$\begin{array}{c}\text { Relative } \\
\text { House }\end{array}$ \\
$\mathrm{HH}$ No. \\
\end{tabular}} & \multirow{2}{*}{\begin{tabular}{|c|}
$\begin{array}{c}\text { Rented } \\
\text { House }\end{array}$ \\
HH No. \\
\end{tabular}} & \multirow{2}{*}{$\begin{array}{c}\text { Tent } \\
\text { HH No. }\end{array}$} & \multirow{2}{*}{$\begin{array}{c}\begin{array}{c}\text { Private } \\
\text { House }\end{array} \\
\text { HH No. } \\
\end{array}$} & \multicolumn{2}{|c|}{ Total } & \multirow{2}{*}{$\begin{array}{c}\begin{array}{c}\text { Relative } \\
\text { House }\end{array} \\
\text { HH No. }\end{array}$} & \multirow{2}{*}{$\begin{array}{c}\text { Rented } \\
\text { House }\end{array}$} & \multirow{2}{*}{$\begin{array}{c}\text { Tent } \\
\text { HH No. }\end{array}$} & \multirow{2}{*}{$\begin{array}{l}\text { Private } \\
\text { House } \\
\text { HH No. }\end{array}$} & \multicolumn{2}{|c|}{ Total } \\
\hline Province & District & & & & & No. & $\%$ & & & & & No. & $\%$ \\
\hline \multirow{2}{*}{ Kabul } & Deh Sabz & & & & & & & & & & & & \\
\hline & Khair Khana & 14939 & 34838 & & & 49777 & 100 & 21673 & 37928 & 3133 & 45632 & 108366 & 100 \\
\hline \multirow{2}{*}{ Khost } & Tani & & & & & & & & & & & & \\
\hline & Ismail Khel & & & & & & & & & & & & \\
\hline Ghazni & Aab Band & & & & & & & & & & & & \\
\hline Paktika & Jani Khel & & & & & & & & & & & & \\
\hline \multicolumn{2}{|r|}{ No. of $\mathrm{HH}$} & 14939 & 34838 & & & 49777 & & 21673 & 37928 & 3133 & 45632 & 108366 & \\
\hline \multicolumn{2}{|r|}{$\%$ of $\mathrm{HH}$} & 30 & 70 & & & 100 & & 20 & 35 & 3 & 42 & 100 & \\
\hline
\end{tabular}

Table (7): Temporary shelter availability and rent:

\begin{tabular}{|c|c|c|c|c|c|c|c|}
\hline \multirow{2}{*}{\multicolumn{2}{|c|}{ Survey localities }} & \multirow{2}{*}{\multicolumn{2}{|c|}{$\begin{array}{c}\text { Shelter available } \\
\text { (tick) }\end{array}$}} & \multirow{2}{*}{\multicolumn{4}{|c|}{$\begin{array}{l}\text { If yes, rent/month/unit } \\
\text { Rate of rent (Rs./month) }\end{array}$}} \\
\hline & & & & & & & \\
\hline Province & District & Tick & (No.) & $(2000)$ & ( & $(\quad)$ & ( \\
\hline \multirow{2}{*}{ Kabul } & Deh Sabz & $\sqrt{ }$ & 4 & $\Pi$ & \multirow{8}{*}{\multicolumn{3}{|c|}{ No rates given except in Khair Khana }} \\
\hline & Khair Khana & $\sqrt{ }$ & 8 & $\sqrt{ }$ & & & \\
\hline \multirow{2}{*}{ Khost } & Tani & $\sqrt{ }$ & 6 & & & & \\
\hline & Ismail Khel & & & & & & \\
\hline Ghazni & Aab Band & $\sqrt{ }$ & 1 & & & & \\
\hline Paktika & Jani Khel & $\sqrt{ }$ & 1 & & & & \\
\hline \multicolumn{2}{|r|}{ Total } & & 20 & 2000 & & & \\
\hline \multicolumn{2}{|r|}{$\%$} & & 40 * & 100 & & & \\
\hline
\end{tabular}

\subsection{The Health status, vaccination services and death cases sense displacement: (Table $8-a \& 8-b$ )}

Related to death cases (table 8-a), in total of 620 death cases of children reported in 4 districts, the death of $322(52 \%)$ have been those above 5 years while $298(48 \%)$ have been those below the 5 years of age. The highest death cases of children above 5 years of age, is $41 \%$ in Jani Khail of Paktika province, while death cases of children less than 5 years of age is 38\% shown in the same district of the same province

In (table 8-b), incidences of diarrhea are reported related to $39 \%$ of adults and $61 \%$ of children in all of the surveyed districts except in Jani Khail of Paktika and Tani district of Khost where no reports are provided.

In table (8-b), offering vaccination services for children by health related organization were reported in all of the surveyed districts as follow: $39 \%$ by WHO, $14 \%$ by Unicef, $14 \%$ by SCA/ WHO, $14 \%$ by NPO, $16 \%$ by Ibn-e-Sina and only $2 \%$ alone by SCA alone.

The average death cases of children $(>5)$ are $52 \%$ in 4 reporting districts while in smaller children $(<5)$ are $48 \%$ in the same districts. On district bases the death cases are high, $41 \%$ and 38\% in Jani Khail of Paktika (see table 8 -a). Death of adults is reported $61 \%$ in male population and $39 \%$ in female. 
Table (8-a): IDPs Health status and death cases since displacement:

\begin{tabular}{|c|c|c|c|c|c|c|c|c|c|c|c|c|c|}
\hline \multirow{3}{*}{\multicolumn{2}{|c|}{ Survey localities }} & \multirow{2}{*}{\multicolumn{4}{|c|}{ Death of Adult }} & \multirow{2}{*}{\multicolumn{2}{|c|}{$\begin{array}{l}\text { Total Adult } \\
\qquad(\mathrm{M}+\mathrm{F})\end{array}$}} & \multicolumn{6}{|c|}{ Death of children } \\
\hline & & & & & & & & \multirow{2}{*}{\multicolumn{2}{|c|}{$5<$}} & \multirow{2}{*}{\multicolumn{2}{|c|}{$5>$}} & \multirow{2}{*}{\multicolumn{2}{|c|}{$\begin{array}{c}\text { Total } \\
5<+5>\end{array}$}} \\
\hline & & \multicolumn{2}{|c|}{ Male } & \multicolumn{2}{|c|}{ Female } & \multirow{2}{*}{ No. } & \multirow{2}{*}{$\%$} & & & & & & \\
\hline Province & District & No. & $\%$ & No. & $\%$ & & & No. & $\%$ & No. & $\%$ & No. & $\%$ \\
\hline \multirow{2}{*}{ Kabul } & Deh Sabz & 97 & 36 & 27 & 16 & 124 & 29 & 71 & 24 & 53 & 16 & 124 & 20 \\
\hline & Khair Khana & 88 & 33 & 63 & 37 & 151 & 35 & 46 & 15 & 54 & 17 & 100 & 16 \\
\hline \multirow{2}{*}{ Khost } & Tani & 47 & 18 & 51 & 30 & 98 & 23 & 67 & 22 & 83 & 26 & 150 & 24 \\
\hline & Ismail Khel & 0 & 0 & 0 & 0 & 0 & 0 & 0 & 0 & 0 & 0 & 0 & 0 \\
\hline Ghazni & Aab Band & 0 & 0 & 0 & 0 & 0 & 0 & 0 & 0 & 0 & 0 & 0 & 0 \\
\hline Paktika & Jani Khel & 34 & 13 & 28 & 17 & 62 & 14 & 114 & 38 & 132 & 41 & 246 & 40 \\
\hline \multicolumn{2}{|c|}{ Total } & 266 & & 169 & & 435 & & 298 & & 322 & & 620 & 100 \\
\hline \multicolumn{2}{|r|}{$\%$} & 61.15 & & 38.85 & & & 100 & & 48 & & 52 & 100 & \\
\hline
\end{tabular}

Table (8-b): Vaccination and incidences of diarrhea:

\begin{tabular}{|c|c|c|c|c|c|c|c|c|c|c|c|c|c|c|c|c|}
\hline \multirow{2}{*}{\multicolumn{2}{|c|}{ Survey localities }} & \multirow{3}{*}{$\begin{array}{l}\text { Reporting } \\
\text { interviews } \\
\text { No. }\end{array}$} & \multicolumn{6}{|c|}{ Participating organization in vaccination } & \multicolumn{2}{|c|}{$\begin{array}{c}\text { Total } \\
\text { responses }\end{array}$} & \multicolumn{6}{|c|}{ Incidences of Diarrhea } \\
\hline & & & \multirow{2}{*}{\begin{tabular}{|l} 
WHO \\
Res. \\
\end{tabular}} & \multirow{2}{*}{\begin{tabular}{|c|} 
Unicef \\
Res. \\
\end{tabular}} & \multirow{2}{*}{$\begin{array}{c}\text { SCA/ WHO } \\
\text { Res. }\end{array}$} & \multirow{2}{*}{$\begin{array}{l}\text { SCA } \\
\text { Res. }\end{array}$} & \multirow{2}{*}{$\begin{array}{l}\text { NPO } \\
\text { Res. }\end{array}$} & \multirow{2}{*}{$\begin{array}{c}\begin{array}{c}\text { Ibn-e- } \\
\text { Sina }\end{array} \\
\text { Res. }\end{array}$} & \multirow[t]{2}{*}{ No. } & \multirow[t]{2}{*}{$\%$} & \multicolumn{2}{|c|}{ Adults } & \multicolumn{2}{|c|}{ Children } & \multicolumn{2}{|c|}{ Total } \\
\hline Province & District & & & & & & & & & & No. & $\%$ & No & $\%$ & No. & $\%$ \\
\hline \multirow{2}{*}{ Kabul } & Deh Sabz & 10 & 10 & & & & & & 10 & 100 & 10 & 0.0 & 25 & 0.0 & 35 & 0.0 \\
\hline & Khair Khana & 8 & 8 & & & & & & 8 & 100 & 132433 & 99.6 & 210911 & 99.5 & 343344 & 99.6 \\
\hline \multirow{2}{*}{ Khost } & Tani & 8 & & & 7 & 1 & & & 8 & 100 & 12 & 0.0 & 23 & 0.0 & 35 & 0.0 \\
\hline & Ismail Khel & 8 & 1 & 7 & & & & & 8 & 100 & 199 & 0.1 & 366 & 0.2 & 565 & 0.2 \\
\hline Ghazni & Aab Band & 8 & & & & & 7 & & 7 & 88 & 296 & 0.2 & 526 & 0.2 & 822 & 0.2 \\
\hline Paktika & Jani Khel & 8 & & & & & & 8 & 8 & 100 & 10 & 0.0 & 53 & 0.0 & 63 & 0.0 \\
\hline \multicolumn{2}{|c|}{ No of response } & 50 & 19 & 7 & 7 & 1 & 7 & 8 & 49 & & 132960 & & 211904 & & 344864 & \\
\hline \multicolumn{2}{|c|}{$\%$ Of response } & & 39 & 14 & 14 & 2 & 14 & 16 & & 98 & & 39 & & 61 & & 100 \\
\hline
\end{tabular}

\subsection{IDPs carried out their physical assets and those lost their physical properties: (Table 9)}

This aspect of the current assessment survey is presented in (table 9). Here, 432 IDPs HHs, mainly in "Tani" and "Ismail Khail" of Khost province have been reported as have carried out their physical assets (household cooking utensil, tea serving set, milk containers, bedding benches "charpaies", sanitary material owner ships, clothing... etc).

Looking at (table 9), at two districts of Kabul, two districts of Khost and Aband district of Ghazni, a total of 189 responses have reported the losses of 8 types of winterization personal properties.

The total number of responses on HHs and (\%) on total bases is shown at the bottom of the two rows of this table. For all personal properties about $47.25 \%$ losses are reported. 
Table (9): Assets carried out \& physical properties lost by IDPs:

\begin{tabular}{|c|c|c|c|c|c|c|c|c|c|c|c|c|c|}
\hline \multirow{2}{*}{\multicolumn{2}{|c|}{ Survey localities }} & \multirow{2}{*}{\multicolumn{2}{|c|}{$\begin{array}{c}\text { HH Carried } \\
\text { Physical } \\
\text { Assets }\end{array}$}} & \multicolumn{8}{|c|}{ Personnel Properties lost (name and No. of response) } & \multicolumn{2}{|c|}{ Total } \\
\hline & & & & \multirow{2}{*}{$\begin{array}{c}\begin{array}{c}\text { Ordinary } \\
\text { clothes }\end{array} \\
\text { Resp. } \\
\end{array}$} & \multirow{2}{*}{\begin{tabular}{|l}
$\begin{array}{l}\text { Warm } \\
\text { Cloth }\end{array}$ \\
Resp. \\
\end{tabular}} & \multirow{2}{*}{$\begin{array}{c}\text { Blanket } \\
\text { Resp. }\end{array}$} & \multirow{2}{*}{\begin{tabular}{|l} 
Patus \\
Resp. \\
\end{tabular}} & \multirow{2}{*}{$\begin{array}{c}\text { Sanitary } \\
\text { Resp. }\end{array}$} & \multirow{2}{*}{\begin{tabular}{|l} 
Quilts \\
Resp. \\
\end{tabular}} & \multirow{2}{*}{\begin{tabular}{|c|} 
Mattress \\
Resp. \\
\end{tabular}} & \multirow{2}{*}{$\begin{array}{l}\begin{array}{l}\text { Other } \\
\text { items }\end{array} \\
\text { Resp. }\end{array}$} & \multirow{2}{*}{ No. } & \multirow{2}{*}{$\%$} \\
\hline Province & District & $\mathrm{HH}(\mathrm{No})$. & $\%$ & & & & & & & & & & \\
\hline \multirow{2}{*}{ Kabul } & Deh Sabz & 0 & 0 & 10 & 10 & 10 & 10 & 10 & 10 & 10 & 10 & 80 & 42 \\
\hline & Khair Khana & 0 & 0 & 8 & 8 & 8 & 8 & 8 & 8 & 8 & 8 & 64 & 34 \\
\hline \multirow{2}{*}{ Khost } & Tani & 394 & 91 & 5 & 5 & 5 & 5 & 5 & 5 & 5 & 5 & 40 & 21 \\
\hline & Ismail Khel & 38 & 9 & 0 & 0 & 0 & 0 & 0 & 0 & 0 & 1 & 1 & 1 \\
\hline Ghazni & Aab Band & 0 & 0 & 0 & 1 & 0 & 0 & 0 & 1 & 1 & 1 & 4 & 2 \\
\hline Paktika & Jani Khel & 0 & 0 & 0 & 0 & 0 & 0 & 0 & 0 & 0 & 0 & 0 & 0 \\
\hline No. 0 & f response & 432 & 100 & 23 & 24 & 23 & 23 & 23 & 24 & 24 & 25 & 189 & 100 \\
\hline \multicolumn{4}{|c|}{ Expected response on each items } & 50 & 50 & 50 & 50 & 50 & 50 & 50 & 50 & 400 & \\
\hline \multicolumn{4}{|c|}{$\%$ Response/ item } & 46 & 48 & 46 & 46 & 46 & 48 & 48 & 50 & 47.25 & \\
\hline
\end{tabular}

\subsection{Fuel local availability for heating and cooking needs of IDPs \& residents: (Table 10)}

(Table 10) presents the status of availability and prices per unit of fuel in the surveyed districts. Except in the district of "Deh Sabz" of Kabul, availability of fuel has been reported in all of the surveyed districts. The prices of liquid fuel (diesel, kerosene) and solid fuel (wood, charcoal \& bush) are presented at the right hand side of (table 10). Here the range of prices of diesel and kerosene on rupees per liter bases are respectively reported at (19-25) Rs./ liter at the $3-4$ surveyed districts. The prices of bush/ $7 \mathrm{~kg}$ collected for selling in 3 districts are reported within the range of (Rs. 1.5 to $13 / 7 \mathrm{~kg}$ ). Charcoal, which used to be a traditionally common fuel coming from Paktia and Konar provinces the forest mountain areas to the big cities population centers, are not reported at this survey except in Khairkhana (Rs. 6/ kg). This status of reporting implies that the potential for making charcoal in forest covered regions have become reduced in lowest level. Variations of prices of liquid fuel within the reported districts are smaller than those of the solid fuel prices. This is due to standard market prices and somehow stable transport cost affecting the liquid fuel consumer prices in the surveyed districts.

Table (10): Fuel locally availability for heating $\&$ cooking $\&$ the prices of fuel in the surveyed districts

\begin{tabular}{|c|c|c|c|c|c|c|c|c|c|}
\hline \multirow{2}{*}{\multicolumn{2}{|c|}{ Survey localities }} & \multirow{2}{*}{\multicolumn{3}{|c|}{$\begin{array}{l}\text { Locally available } \\
\text { (tick and give number of } \\
\text { responses) }\end{array}$}} & \multicolumn{5}{|c|}{ If available give price Rs. / Unit } \\
\hline & & & & & \multirow{2}{*}{$\begin{array}{l}\text { Wood } \\
\text { Rs. / Kg } \\
\end{array}$} & \multirow{2}{*}{$\begin{array}{l}\text { Charcoal } \\
\text { Rs. / Kg } \\
\end{array}$} & \multirow{2}{*}{$\begin{array}{l}\text { Diesel } \\
\text { Rs. / lit. } \\
\end{array}$} & \multirow{2}{*}{$\begin{array}{c}\text { Kerosene } \\
\text { Rs. / lit. } \\
\end{array}$} & \multirow{2}{*}{$\begin{array}{c}\text { Bush } \\
\text { Rs. / Kg }\end{array}$} \\
\hline Province & District & Yes & (No.) & $\%$ & & & & & \\
\hline \multirow[t]{2}{*}{ Kabul } & Deh Sabz & & & & 0 & 0 & 0 & 0 & 0.0 \\
\hline & Khair Khana & $\sqrt{ }$ & 8 & 24 & 4 & 6 & 19 & 20 & 4.0 \\
\hline \multirow[t]{2}{*}{ Khost } & Tani & $\sqrt{ }$ & 8 & 24 & 1 & 0 & 20 & 25 & 0.0 \\
\hline & Ismail Khel & $\sqrt{ }$ & 8 & 24 & 2 & 0 & 0 & 25 & 0.0 \\
\hline Ghazni & Aab Band & $\sqrt{ }$ & 2 & 6 & 3 & 0 & 20 & 20 & 13.0 \\
\hline Paktika & Jani Khel & $\sqrt{ }$ & 8 & 24 & 0 & 0 & 0 & 0 & 1.5 \\
\hline & Total & & 34 & 100 & 10 & 6 & 59 & 90 & 18.5 \\
\hline \multicolumn{2}{|c|}{ Average price } & & & & 2.6 & 6.0 & 19.8 & 22.6 & 6.2 \\
\hline
\end{tabular}




\subsection{Food items availability and the prices given: (Table 11)}

The food availability and prices are illustrated in (table 11). Here from expected 50 responses in 6 surveyed districts, only 15 responses in 5 districts have indicated the local availability of food items in the surveyed areas. The highest response rate (53\%) confirming local food availability, is reported in "Khairkhana" district of Kabul. The main types of available food prices reported in the same table are for wheat 12 Rs./ kg, wheat flour 13.2 Rs./ kg, rice 18 Rs./ kg, cooking oil 54.4 Rs./ kg, bean 33.5 Rs./ $\mathrm{kg} \&$ mong bean $26 \mathrm{Rs} . / \mathrm{kg}$. From the expected 50 responses, reporting of only 15 responses $(30 \%)$ is a clear indicator of shortage of main food items in the six surveyed districts. In Ismail Khail district of Khost food availability is not reported at all. This could have been an exception just to show the poverty in surveyed areas for attracting assistance from outside.

Table (11): Food items available and prices:

\begin{tabular}{|c|c|c|c|c|c|c|c|c|c|c|}
\hline \multirow{2}{*}{\multicolumn{2}{|c|}{ Survey localities }} & \multirow{2}{*}{\multicolumn{3}{|c|}{$\begin{array}{c}\text { Locally available (tick) \& } \\
\text { No. of response }\end{array}$}} & \multicolumn{6}{|c|}{ If available give prices* } \\
\hline & & & & & \multirow{2}{*}{$\begin{array}{l}\text { Wheat } \\
\text { Rs. / Kg }\end{array}$} & \multirow{2}{*}{$\begin{array}{c}\text { Flour } \\
\text { Rs. / Kg } \\
\end{array}$} & \multirow{2}{*}{$\begin{array}{c}\text { Rice } \\
\text { Rs. / Kg } \\
\end{array}$} & \multirow{2}{*}{$\begin{array}{c}\text { Cooking Oil } \\
\text { Rs. / Kg } \\
\end{array}$} & \multirow{2}{*}{$\begin{array}{l}\text { Beans } \\
\text { Rs./ kg }\end{array}$} & \multirow{2}{*}{$\begin{array}{c}\text { Mong Bean } \\
\text { Rs. } / \mathrm{Kg} \\
\end{array}$} \\
\hline Province & District & Yes & (No.) & $\%$ & & & & & & \\
\hline \multirow{2}{*}{ Kabul } & Deh Sabz & & & & & & & & & \\
\hline & Khair Khana & $\sqrt{ }$ & 8 & 53 & 13 & 14 & & 50 & & \\
\hline \multirow{2}{*}{ Khust } & Tani & $\sqrt{ }$ & 1 & 7 & & 14 & 15 & 57 & & 20 \\
\hline & Ismail Khel & & & 0 & & & & & & \\
\hline Ghazni & Aab Band & $\sqrt{ }$ & 3 & 20 & & 13 & 21 & 63 & 34 & 32 \\
\hline Paktika & Jani Khel & $\sqrt{ }$ & 3 & 20 & 11 & 12 & & 48 & & \\
\hline \multicolumn{2}{|c|}{ Total } & & 15 & 100 & 24 & 53 & 36 & 218 & 34 & 52 \\
\hline \multicolumn{2}{|c|}{ Average } & & & & 12.0 & 13.2 & 18.0 & 54.4 & 33.5 & 26.0 \\
\hline
\end{tabular}

\subsection{IDPs location from where they have moved in to the sample surveyed districts, and the IDPs HHs expected to move out from their present location: (Table 12-a \& 12-b)} These two aspects of IDPs status (moved in to and expected move out) are reported in (table 12-a) and (table 12-b). These original locations that IDPs have moved in to the 6 sample surveyed districts are basically the four main areas of Kabul, Khost, Qataghan and Shamali areas in north of Kabul.

The date of arrival to the surveyed district at last column of (table 12-a), indicates duration of $(11 / 09 / 2001-10 / 10 / 2001)$ for arrival of IDPs and the reasons for displacement. Based on these reasons (about 70\%) of displacement have been due to the U.S. air strikes and civil war in general while the other $30 \%$ have reported drought, poverty, and un-security as the remaining reasons for becoming IDPs.

Related to IDPs expected moving out from the present settled district, (table 12-b), 54\% of the respondents have indicated "don't know" $37 \%$ have said not moving out while only $9 \%$ have said "yes moving out". But the places where they will move out have been indicated Pakistan and their home location inside the country. 
Table (12-a): The places from where the IDPs moved in to the surveyed districts \& the reasons for their displacement

\begin{tabular}{|c|c|c|c|c|c|c|c|c|c|c|c|c|c|c|}
\hline \multicolumn{2}{|c|}{ Survey localities } & \multicolumn{4}{|c|}{ Location Moved in From } & \multirow{2}{*}{ Total } & \multicolumn{5}{|c|}{ Reasons for Displacement } & \multicolumn{2}{|c|}{ Total } & \multirow{2}{*}{$\begin{array}{l}\text { Date of } \\
\text { Arrival }\end{array}$} \\
\hline Province & District & Kabul & Khost & Qataghan & Shamali & & Drought & Poorness & $\begin{array}{c}\text { Un- } \\
\text { security }\end{array}$ & $\begin{array}{c}\text { US } \\
\text { Attack }\end{array}$ & War & No. & $\%$ & \\
\hline \multirow{2}{*}{ Kabul } & Deh Sabz & 10 & & & 3 & 13 & & & & 4 & 5 & 9 & 20 & $11 / 9 / 2001$ \\
\hline & Khair Khana & 8 & & 1 & 8 & 17 & 8 & & & & 8 & 16 & 36 & $1 / 1 / 1998$ \\
\hline \multirow{2}{*}{ Khost } & Tani & 3 & 8 & & & 11 & & & 3 & 5 & & 8 & 18 & $15 / 09 / 2001$ \\
\hline & Ismail Khel & 8 & 8 & & & 16 & 1 & 1 & & 8 & & 10 & 22 & $13 / 9 / 2001$ \\
\hline Ghazni & Aab Band & & & & 1 & 1 & 1 & & & 1 & & 2 & 4 & $10 / 10 / 2001$ \\
\hline Paktika & Jani Khel & & & & & & & & & & & 0 & 0 & \\
\hline \multicolumn{2}{|c|}{ Total Response } & 29 & 16 & 1 & 12 & 58 & 10 & 1 & 3 & 18 & 13 & 45 & 100 & \\
\hline \multicolumn{7}{|c|}{$\%$ Of total } & 22 & 2 & 7 & 40 & 29 & 100 & & \\
\hline
\end{tabular}

Table (12-b): Estimated IDPS Household Move out from the Surveyed areas

\begin{tabular}{|c|c|c|c|c|c|c|c|c|c|}
\hline \multicolumn{2}{|c|}{ Survey localities } & \multicolumn{3}{|c|}{ IDPS moving out } & \multicolumn{2}{|c|}{ Total } & \multicolumn{3}{|c|}{$\begin{array}{c}\text { If yes to where ( name the place) } \\
\text { and give the HH No. }\end{array}$} \\
\hline & \multirow[b]{2}{*}{ District } & \multirow[b]{2}{*}{ Yes } & \multirow[b]{2}{*}{ No. } & \multirow[b]{2}{*}{ Don't know } & \multirow[b]{2}{*}{ No. } & \multirow[b]{2}{*}{$\%$} & \multirow{2}{*}{$\begin{array}{l}\text { Pakistan } \\
\text { HH No. }\end{array}$} & \multirow{2}{*}{$\begin{array}{c}\text { Their home } \\
\text { HH No. }\end{array}$} & \multirow{2}{*}{ HH No. } \\
\hline Province & & & & & & & & & \\
\hline \multirow[t]{2}{*}{ Kabul } & Deh Sabz & & 7 & 3 & 10 & 29 & & & \\
\hline & Khair Khana & 2 & 6 & & 8 & 23 & * & & \\
\hline \multirow{2}{*}{ Khust } & Tani & 1 & & 7 & 8 & 23 & & * & \\
\hline & Ismail Khel & & & 8 & 8 & 23 & & & \\
\hline Ghazni & Aab Band & & & 1 & 1 & 3 & & & \\
\hline Paktika & Jani Khel & & & & 0 & 0 & & & \\
\hline \multicolumn{2}{|c|}{ Total Response } & 3 & 13 & 19 & 35 & & & & \\
\hline \multicolumn{2}{|c|}{$\%$ Of Total } & 9 & 37 & 54 & & 100 & & & \\
\hline
\end{tabular}

\subsection{Urgent needs reported by IDPs and residents households: (Table 13- $a$ \& $13-b$ )}

The urgent needs of IDPs HHs are reported in (table 13-a) and of the residents in (table 13-b). It is illustrated that on district bases winterization needs, shelter, door, windows and wooden beams are the main shelter items for IDPs. For the residents HHs, almost the same items have been indicated highly important

Table (13-a): Urgent needs to make IDPs HH temporary shelter suitable to live

\begin{tabular}{|c|c|c|c|c|c|c|c|c|c|c|c|c|}
\hline \multicolumn{2}{|c|}{ Survey localities } & \multicolumn{10}{|c|}{ IDP's Name of the needs. } & \multirow{3}{*}{$\begin{array}{c}\begin{array}{c}\text { Total } \\
\text { need } \\
\text { Items }\end{array} \\
\text { No. }\end{array}$} \\
\hline & & \multirow{2}{*}{ Blanket } & \multirow{2}{*}{$\begin{array}{c}\text { Doors/ } \\
\text { windows }\end{array}$} & \multirow{2}{*}{$\begin{array}{l}\text { Emergency } \\
\text { Relief aid }\end{array}$} & \multirow{2}{*}{$\begin{array}{c}\text { Floor } \\
\text { covering }\end{array}$} & \multirow{2}{*}{$\begin{array}{l}\text { Food } \\
\text { items }\end{array}$} & \multirow{2}{*}{ Glasses } & \multirow{2}{*}{ Latrine } & \multirow{2}{*}{$\begin{array}{l}\text { Winterization } \\
\text { needs }\end{array}$} & \multirow{2}{*}{ Shelter } & \multirow{2}{*}{$\begin{array}{l}\text { Wooden } \\
\text { beams }\end{array}$} & \\
\hline Province & District & & & & & & & & & & & \\
\hline \multirow[t]{2}{*}{ Kabul } & Deh Sabz & 6 & & & & 1 & & & 25 & & & 32 \\
\hline & Khair Khana & & & 2 & & 4 & 5 & & 16 & & & 27 \\
\hline \multirow[t]{2}{*}{ Khost } & Tani & & & 1 & 4 & & & & 12 & 5 & & 22 \\
\hline & Ismail Khel & & 8 & & & & & & 8 & 8 & 8 & 32 \\
\hline Ghazni & Aab Band & & & & & & & 1 & 1 & & & 2 \\
\hline Paktika & Jani Khel & & & & & & & & 0 & & & 0 \\
\hline \multicolumn{2}{|c|}{ No of response } & 6 & 8 & 3 & 4 & 5 & 5 & 1 & 62 & 13 & 8 & 115 \\
\hline \multicolumn{2}{|c|}{$\%$ of total responses } & 5 & 7 & 3 & 3 & 4 & 4 & 1 & 54 & 11 & 7 & 100 \\
\hline
\end{tabular}


Table (13-b): Urgent needs to make residents HH temporary shelter suitable to live:

\begin{tabular}{|c|c|c|c|c|c|c|c|c|c|c|c|c|}
\hline \multicolumn{2}{|c|}{ Survey localities } & \multicolumn{10}{|c|}{ Residents Name of the needs } & \multirow{3}{*}{\begin{tabular}{|l}
$\begin{array}{l}\text { Total } \\
\text { need } \\
\text { Items }\end{array}$ \\
No. \\
\end{tabular}} \\
\hline & & \multirow{2}{*}{ Blanket } & \multirow{2}{*}{$\begin{array}{l}\text { Doors/ } \\
\text { windows }\end{array}$} & \multirow{2}{*}{$\begin{array}{l}\text { Floor } \\
\text { covering }\end{array}$} & \multirow{2}{*}{$\begin{array}{l}\text { Food } \\
\text { items }\end{array}$} & \multirow{2}{*}{ Glasses } & \multirow{2}{*}{ Job } & \multirow{2}{*}{$\begin{array}{l}\text { Winterization } \\
\text { needs }\end{array}$} & \multirow{2}{*}{ Latrine } & \multirow{2}{*}{ Shelter } & \multirow{2}{*}{$\begin{array}{c}\text { Wooden } \\
\text { beams }\end{array}$} & \\
\hline Province & District & & & & & & & & & & & \\
\hline \multirow{2}{*}{ Kabul } & Deh Sabz & 1 & 9 & 1 & 1 & 1 & & 18 & 18 & 1 & & 50 \\
\hline & Khair Khana & & & & & 7 & 6 & 13 & 13 & & & 39 \\
\hline \multirow{2}{*}{ Khust } & Tani & & & & & & & 0 & 0 & 8 & & 8 \\
\hline & Ismail Khel & & & & & & & 0 & 0 & & & 0 \\
\hline Ghazni & Aab Band & & & & & & & 1 & 1 & & & 2 \\
\hline Paktika & Jani Khel & & 6 & 3 & & 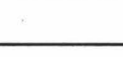 & & 1 & 1 & & 4 & 15 \\
\hline \multicolumn{2}{|c|}{ No of response } & 1 & 15 & 4 & 1 & 8 & 6 & 33 & 33 & 9 & 4 & 114 \\
\hline \multicolumn{2}{|c|}{$\%$ of total responses } & 1 & 13 & 4 & 1 & 7 & 5 & 29 & 29 & 8 & 4 & 100 \\
\hline
\end{tabular}

\subsection{Marketing problems related to locally produced cash crops and market price of the main consumer items: (Table 14, $15 \& 16$ )}

The main cash crops produced for selling were reported potatoes, onions, carrots and apples (table 14). Marketing problems related to these crops (table 15) are reported as follows:

In four of the six surveyed districts, 7 responses (14\%) have reported "high transport cost", 4 responses $(8 \%)$ in 3 districts have indicated, "storage problems" and 3 responses $(6 \%)$ have shown "lower local price" as one of the local marketing problems in the surveyed areas.

On prices of main consumers items, (table 16) summarizes the reporting of the current emergency survey. In this table, "food grain", "cooking oil", "beef", "mutton" and "liquid fuel" prices are given for all of the surveyed districts.

Considering the variation of prices of consumer items on district bases, benzene has the least variation within the surveyed district (st. d. =2.9). Following to this is the slightly higher price variation within the surveyed districts for cooking oil (st. d. = 3.2). For wheat flour as the main food items (st. d. = 3.4), mutton prices, which depend on the local, supply (stock of sheep) and its difference within the district has the highest variation in the surveyed district (st.d. = 21.1). The reasons for higher variation in mutton prices are due to the large range variation within the two districts of Deh Sabz of Kabul and Ismail Khail of Khost (table 16). These lower price in the two districts of Khost are due to the location of these districts in the crossing path of Kochies from Afghanistan to Pakistan, and boundary location of offering of sheep at low price by Kochies to the Khost (Tani \& Ismail Khail) districts.

Table (14): Cash crops locally produced and their local prices:

\begin{tabular}{|c|c||c|c|c|c|c|}
\hline \multicolumn{2}{|c||}{ Survey localities } & \multicolumn{5}{c|}{ Name of the main cash crops and price/kg } \\
\cline { 3 - 7 } \multicolumn{2}{|c||}{} & Potatoes & Onion & Carrots & Apples & Others (name) \\
\hline Province & District & Rs./Kg & Rs./Kg & Rs./Kg & Rs./Kg & Rs./Kg \\
\hline \hline \multirow{2}{*}{ Kabul } & Deh Sabz & $0^{*}$ & $0^{*}$ & $0^{*}$ & $0^{*}$ & \\
\cline { 2 - 7 } & Khair Khana & 10 & 4 & 10 & 70 & \\
\hline \multirow{2}{*}{ Khost } & Tani & 10 & 7 & 5 & 16 & \\
\cline { 2 - 7 } & Ismail Khel & 0 & $0^{*}$ & $0^{*}$ & $0^{*}$ & \\
\hline \multirow{2}{*}{ Ghazni } & Aab Band & 7 & $0^{*}$ & $0^{*}$ & $0^{*}$ & \\
\hline Paktika & Jani Khel & 10 & 3 & 4 & 13 & \\
\hline \multicolumn{2}{|c||}{ Total } & 37 & 14 & 19 & 98 & \\
\hline \multicolumn{2}{|c||}{ Average } & 9.25 & 4.6 & 6.3 & 33 & \\
\hline
\end{tabular}

* Not reported 
Table (15): Marketing problems on locally produced cash crops:

\begin{tabular}{|c|c|c|c|c|c|c|c|}
\hline \multirow{2}{*}{\multicolumn{2}{|c|}{ Survey localities }} & \multicolumn{5}{|c|}{ Marketing Problems } & \multirow{3}{*}{$\begin{array}{c}\text { Total } \\
\text { response }\end{array}$} \\
\hline & & \multirow{2}{*}{$\begin{array}{c}\text { High } \\
\text { transport cost } \\
\text { Response }\end{array}$} & \multirow{2}{*}{\begin{tabular}{|c|}
$\begin{array}{c}\text { Un-security of } \\
\text { transport }\end{array}$ \\
Response \\
\end{tabular}} & \multirow{2}{*}{$\begin{array}{c}\begin{array}{c}\text { Storage } \\
\text { problems }\end{array} \\
\text { Response } \\
\end{array}$} & \multirow{2}{*}{$\begin{array}{c}\begin{array}{c}\text { Lower local } \\
\text { prices }\end{array} \\
\text { Response }\end{array}$} & \multirow{2}{*}{\begin{tabular}{|l|}
$\begin{array}{l}\text { Others } \\
\left(\text { name }^{\star}\right)\end{array}$ \\
Response
\end{tabular}} & \\
\hline Province & District & & & & & & \\
\hline \multirow[t]{2}{*}{ Kabul } & Deh Sabz & 2 & & & & & 2 \\
\hline & Khair Khana & & & & & & 0 \\
\hline \multirow{2}{*}{ Khust } & Tani & 2 & & 2 & & & 4 \\
\hline & Ismail Khel & & & & 1 & & 1 \\
\hline Ghazni & Aab Band & 2 & & 1 & 2 & & 5 \\
\hline Paktika & Jani Khel & 1 & & 1 & & & 2 \\
\hline \multicolumn{2}{|c|}{ No. of given response } & 7 & & 4 & 3 & & 14 \\
\hline \multicolumn{2}{|c|}{ Expected No. of response } & 50 & 50 & 50 & 50 & 50 & 50 \\
\hline \multicolumn{2}{|c|}{$\%$ of given response } & 14 & & 8 & 6 & & 28 \\
\hline
\end{tabular}

Table (16): The market price of the main consumer items:

\begin{tabular}{|c|c|c|c|c|c|c|c|c|c|c|}
\hline \multirow{2}{*}{\multicolumn{2}{|c|}{ Survey localities }} & \multicolumn{9}{|c|}{ Consumer items and prices (Rs./Kg) } \\
\hline & & \multirow{2}{*}{$\begin{array}{c}\text { Wheat flour } \\
\text { Rs. / Kg }\end{array}$} & \multirow{2}{*}{$\frac{\text { Rice }}{\text { Rs. / Kg }}$} & \multirow{2}{*}{$\frac{\text { Beans }}{\text { Rs. / Kg }}$} & \multirow{2}{*}{\begin{tabular}{|c|} 
Mong Beans \\
Rs. / Kg
\end{tabular}} & \multirow{2}{*}{$\begin{array}{c}\text { Cooking Oil } \\
\text { Rs. / Kg }\end{array}$} & \multirow{2}{*}{\begin{tabular}{c|} 
Beef \\
Rs. / Kg
\end{tabular}} & \multirow{2}{*}{$\begin{array}{l}\text { Mutton } \\
\text { Rs. / Kg }\end{array}$} & \multirow{2}{*}{\begin{tabular}{|l|} 
Kerosene \\
Rs. / Kg \\
\end{tabular}} & \multirow{2}{*}{\begin{tabular}{|l} 
Benzene \\
Rs. / Kg
\end{tabular}} \\
\hline Province & District & & & & & & & & & \\
\hline \multirow{2}{*}{ Kabul } & Deh Sabz & 18 & 40 & 55 & 55 & 50 & 80 & 100 & 35 & 25 \\
\hline & Khair Khana & 14 & 28 & 28 & 28 & 47 & 70 & 90 & 18 & 23 \\
\hline \multirow{2}{*}{ Khost } & Tani & 9 & 13 & 31 & 18 & 48 & 55 & 71 & 22 & 19 \\
\hline & Ismail Khel & 10 & 23 & 23 & 20 & 55 & 55 & 70 & 25 & 25 \\
\hline Ghazni & Aab Band & 10 & 17 & 40 & 32 & 46 & 70 & 95 & 24 & 19 \\
\hline Paktika & Jani Khel & 12 & 10 & 45 & & 48 & 70 & & 20 & 20 \\
\hline \multicolumn{2}{|r|}{ Total } & 73 & 131 & 222 & 153 & 294 & 400 & 426 & 144 & 131 \\
\hline \multicolumn{2}{|c|}{ Average } & 12.2 & 21.8 & 37.0 & 25.5 & 49.0 & 66.7 & 71.0 & 23.9 & 21.8 \\
\hline \multicolumn{2}{|c|}{ Standard Deviation } & 3.4 & 11 & 11.9 & 15.9 & 3.2 & 9.8 & 21.1 & 6.1 & 2.9 \\
\hline
\end{tabular}

\subsection{Livestock lost from IDPs and residents villagers: (Table 17)}

The questions in the survey form on "livestock losses" were all arranged on "heads" of livestock bases, but due to the field operation problems, the surveyor have converted the information from the sources obtained into (\% lost). According to this type of estimate the average (\%) losses of livestock is illustrated in (table 17) for both "IDPs" and "residents" villagers in the surveyed districts.

Here in this table the loss of livestock (cows, goats/ sheep, donkeys \& camels) are reported on average (\%) bases in the last row of the table. On comparative bases higher average (\%) losses of livestock are reported in residents population compared to IDPs. This could be due to risks of drought and shortage of feeding in wider scope in resident surveyed communities of the targeted districts. 
Table (17): Livestock lost from IDPs and resident villagers

\begin{tabular}{|c|c|c|c|c|c|c|c|c|c|}
\hline \multicolumn{2}{|c|}{ Survey localities } & \multicolumn{4}{|c|}{$\%$ Lost from IDPs } & \multicolumn{4}{|c|}{$\%$ Lost from Residents } \\
\hline Province & District & Cow & Goats/Sheep & Donkeys & Camels & Cow & Goats/Sheep & Donkeys & Camels \\
\hline \multirow{2}{*}{ Kabul } & Deh Sabz & 100 & 100 & 100 & & 74 & 66 & 68 & \\
\hline & Khair Khana & 100 & 100 & 100 & & 0 & 0 & 0 & \\
\hline \multirow{2}{*}{ Khust } & Tani & 53 & 43 & 22 & & 54 & 60 & 12 & 3 \\
\hline & Ismail Khel & 0 & 0 & 0 & & 0 & 0 & 0 & 0 \\
\hline Ghazni & Aab Band & 0 & 11 & 0 & & 90 & 76 & & \\
\hline Paktika & Jani Khel & 0 & 0 & 0 & & 95 & 95 & 95 & \\
\hline \multicolumn{2}{|r|}{ Total } & 253 & 254 & 222 & 0 & 313 & 297 & 175 & 3 \\
\hline \multicolumn{2}{|r|}{$\%$} & 35 & 35 & 30 & 0 & 52 & 49 & 29 & 1 \\
\hline
\end{tabular}

\subsection{Surveyor's observations \& comments on situation of surveyed districts:}

In each district, surveyor's comments on needs and problems are summarized in table (v). In this table surveyors have given a total of 22 comments on lack of doctors, clinic, midwife and primary health education as the needs for four of the survey districts. In the same series lack of drinking water has been indicated in four districts by 16 responses. Damaging of drought, shortage of irrigation water is followed to these problems. Other problems on district bases focused by surveyors in the same table (18) are distributed within the six surveyed districts. In Khairkhana 6 main problems/ needs, in Deh Sabz 5, in Tani 10 and in Ismail Khail of Khost 6 problems are pinpointed through surveyor's observations. In "Aband" of Ghazni and "Jani Khail" of Paktika 3 problems in each are identified by the surveyors. (see table 18, surveyors comments).

Table (18): Surveyors comments and problems identification on district bases:

\begin{tabular}{|c|c|c|c|c|c|c|c|c|c|}
\hline Identified Problems & $\begin{array}{c}\text { Khairkhana } \\
\text { Comment } \\
\text { (No.) }\end{array}$ & $\begin{array}{c}\text { Deh Sabz } \\
\text { Comment } \\
\text { (No.) }\end{array}$ & $\begin{array}{c}\text { Tani } \\
\text { Comment } \\
\text { (No.) }\end{array}$ & $\begin{array}{l}\text { Ismail Khail } \\
\text { Comment } \\
\text { (No.) }\end{array}$ & $\begin{array}{l}\text { Aband } \\
\text { Comment } \\
\text { (No.) }\end{array}$ & $\begin{array}{c}\text { Jani Khail } \\
\text { Comment } \\
\text { (No.) }\end{array}$ & $\begin{array}{c}\text { Total } \\
\text { Comment } \\
\text { (No.) } \\
\end{array}$ & $\%$ & Rank \\
\hline $\begin{array}{l}\text { Lack of doctors, clinics, midwifes } \\
\& \text { primary heath education }\end{array}$ & 7 & & 7 & 2 & 6 & & 22 & 14 & 1 \\
\hline Need for humanitarian assistance & 8 & 2 & 1 & & & 8 & 19 & 12 & 2 \\
\hline Lack of drinking water sources & & 6 & 3 & 7 & & 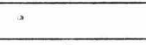 & 16 & 10 & 3 \\
\hline High damaging drought & & 6 & & 7 & & 3 & 16 & 10 & 3 \\
\hline Shortage of Irrigation water & & 7 & & 3 & 6 & & 16 & 10 & 3 \\
\hline Lack of employment opportunities & 8 & & 7 & & & & 15 & 9 & 4 \\
\hline Need for road construction & & & 1 & 4 & 6 & & 11 & 7 & 5 \\
\hline Food items needs & 8 & 1 & & & & & 9 & 6 & 6 \\
\hline Lack of school \& education services & & & 6 & 2 & & & 8 & 5 & 7 \\
\hline $\begin{array}{l}\text { Psychological problems within the } \\
\text { district }\end{array}$ & 8 & & & & & & 8 & 5 & 7 \\
\hline Winterization needs & 8 & & & & & & 8 & 5 & 7 \\
\hline Shortage of safe water supply & & & 6 & & & & 6 & 4 & 8 \\
\hline $\begin{array}{l}\text { Suffering of people from common } \\
\text { diseases }\end{array}$ & & & 1 & & & & 1 & 1 & 9 \\
\hline Lack of training for finding jobs & & & 1 & & & & 1 & 1 & 9 \\
\hline $\begin{array}{l}\text { Women over burden in out of house } \\
\text { jobs }\end{array}$ & & & 1 & & & & 1 & 1 & 9 \\
\hline Need of fuel for cooking \& heating & & & & & & 1 & 1 & 1 & 9 \\
\hline Total responses & & & & & & & 158 & 100 & \\
\hline Types of problems (No.) & 6 & 5 & 10 & 6 & 3 & 3 & & & \\
\hline
\end{tabular}


ANNEX - 1

\section{SURVEY FORM}




\section{CARE Afghanistan Assessment of Humanitarian Status (Victims/ Displaced Population Profile)}

Date of interview:

\section{Introduction:}

Location:

\begin{tabular}{|c|c|c|c|c|c|}
\hline \multirow[b]{2}{*}{ Province } & \multirow[b]{2}{*}{ District } & \multirow[b]{2}{*}{ Community } & \multirow[b]{2}{*}{ Village } & \multicolumn{2}{|c|}{ Distance from $(\mathrm{km})$} \\
\hline & & & & $\begin{array}{l}\text { Nearest CARE } \\
\text { office }\end{array}$ & $\begin{array}{l}\text { Nearest } \\
\text { market }\end{array}$ \\
\hline
\end{tabular}

Sources of information please tick mark $(\sqrt{ })$ before starting filling the form:

- Focus group ( ) No. of individual

- Key informant ( ) Name__ profession

- Group meeting ( ) No. in the group

- Observation ( )

- CARE regional manager( ) position

- Authorities ( ) position

- IDP household head ( )

CARE projects in the village or area:

- No , Yes

- If yes, specify
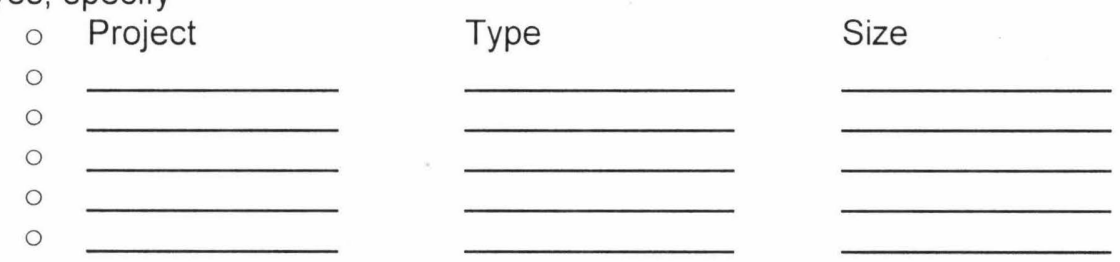

Other NGO's project in the village or area:

- No Yes

- If yes, specify
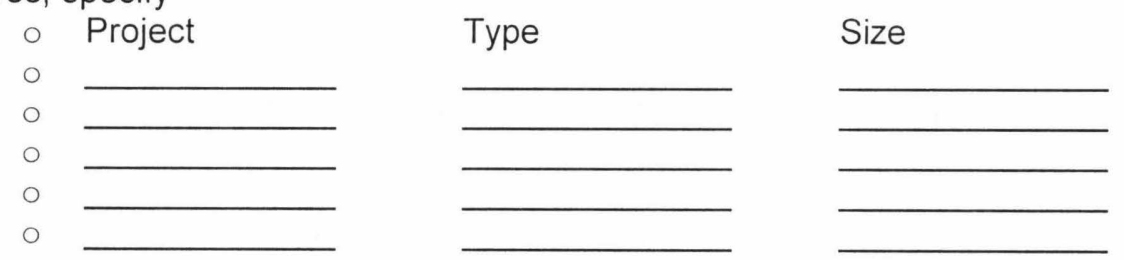


\section{General Aspects:}

1) Population:

\begin{tabular}{|l|l|l|l|l|l|l|}
\hline \multirow{2}{*}{ Status } & \multicolumn{2}{|l|}{ \# Most vulnerable $\mathrm{HH}^{*}$} & $\begin{array}{l}\text { Vulnerable } \\
\text { HHs \# }\end{array}$ & $\begin{array}{l}\text { Non-vulnerable } \\
\text { HHs \# }\end{array}$ \\
\cline { 2 - 6 } & Widow & Shaikh Fani & Disabled & & & \\
\hline Residents & & & & & & \\
\hline IDPs & & & & & & \\
\hline
\end{tabular}

i. IDPs location came from:

ii. IDPs present location in the village:

iii. Starting date of IDPs arrival:

iv. Reasons for displacement:

2) Are they moving out: Yes ( ) No ( ) Don't know ( )

i. If yes, to where:

ii. Estimated IDPs moving out, $\mathrm{HH}$ No.

iii. If don't know why?

3) Estimated IDPs arrival/ week: HH No.

\section{Family/ group structure and living aspects:}

1) Average $\mathrm{HH}$ size on age and gender bases:

\begin{tabular}{|l|c|c|c|c|c|c|}
\hline \multirow{2}{*}{ Gender } & \multicolumn{2}{|c|}{ Under 5 } & \multicolumn{2}{c|}{ Aged 6-14 } & \multicolumn{2}{c|}{ Adults 15 \& over } \\
\cline { 2 - 7 } & IDPs & Residents & IDPs & Residents & IDPs & Residents \\
\hline Male & & & & & & \\
\hline Female & & & & & & \\
\hline Total & & & & & & \\
\hline
\end{tabular}

2) Typical original living style :

- Sedentary HH, No. nomadic $\mathrm{HH}$, No.

3) Customary basic diet (to be checked):

\begin{tabular}{|l|l|l|l|l|l|l|l|l|}
\hline & Bread & Vegetable & Rice & Gee/ oil & Tea & Sugar & Onion & Meat \\
\hline IDPs & & & & & & & & \\
\hline Residents & & & & & & & & \\
\hline
\end{tabular}

4) A) Type of shelters:

\begin{tabular}{|l|l|l|l|l|l|l|l|l|}
\hline \# Of HHs & Mosque & $\begin{array}{l}\text { Relative } \\
\text { house }\end{array}$ & $\begin{array}{l}\text { Rented } \\
\text { house }\end{array}$ & Tent & \multicolumn{2}{l|}{$\begin{array}{l}\text { Private } \\
\text { house }\end{array}$} & \multicolumn{2}{|l|}{ Other buildings specify } \\
\cline { 6 - 10 } & & & & & & & & \\
\hline IDPs & & & & & & & & \\
\hline Residents & & & & & & & & \\
\hline
\end{tabular}

* Notes:

1. Most vulnerable: Very old (shaik fani), widow, disable, orphans or who do not have anybody to work and also without any means of income.

2. Vulnerable: One who does not have money for his/ her family daily expenses for food and does not have the opportunity to work. And those who are deeply affected by drought...

3. Non-vulnerable: One who can live without external support

HH (Household): Man, woman and children a core family. 
B) Temporary shelter:

Locally available yes ( ), No ( )

- If no why?

- If yes, rent/ month/ unit

- General comments:

5) What are the urgent needs to make your temporary shelter suitable to live?

$\begin{array}{ll}\text { 1. } & \text { IDPs } \\ 2 . & 2 . \\ 3 . & 3 .\end{array}$

6) Socio-economics status:

IDPs Residents

- Government employee HH No.

- Self employee, HH No.

- Daily workers, HH No.

- Others, HH No.

III. Health status and death cases since displacement:

1) Death of adults: Male No.

2) Death of children $5<$ : Boys No. Female No

3) Death of children 5> : Boys No.

4) Cause of death (name causes):

5) Crude adult + children) mortality since displacement, No.

6) Children vaccinated,

7) Incidences of diarrhea: adults No. $\%$ by whom

8) The most common diseases, (name) , children No.

IV. Capacity and assets:

1) No. of literate people, Male No. Female No.

2) IDP emergency related skills (name of skills):

Skill
Skill
Skill
No. of individual No. of individual No. of individual

3) Assets carried out by IDP HHs.

- Physical assets (carpets, bedding, utensils) HH No.

4) Properties or items lost:

i) Personal properties lost:

Ordinary clothes

Cold weather clothe

Blankets

Patus

Sanitary items

Quilts

Mattress 
ii) Livestock lost:

\begin{tabular}{|l|c|l|l|l|}
\hline \multirow{2}{*}{$\begin{array}{l}\text { Livestock } \\
\text { Type }\end{array}$} & \multicolumn{3}{|l|}{ Lost (head0 } & \multicolumn{2}{l|}{ Remain (head) } \\
\hline & IDPs & Residents & IDPS & Residents \\
\hline & & & & \\
\hline & & & & \\
\hline & & & & \\
\hline & & & & \\
\hline & & & & \\
\hline
\end{tabular}

iii) Heating/ cooking needs (fuel):

- Locally available yes ( ), No ( )

\begin{tabular}{|l|l|l|l|l|l|l|}
\hline \multirow{2}{*}{ Price/ unit } & Wood/ kg & Charcoal/ kg & Diesel/ lit & Kerosene/ lit & Bush/ 7kg & \\
\cline { 2 - 7 } & & & & & \\
\hline
\end{tabular}

- If No, why:

- General comments:

c) Food items (wheat, Flour, Vegetables, Cooking oil......)

- Locally available yes ( ), No ( )

- If No, why:

- If yes, piece:

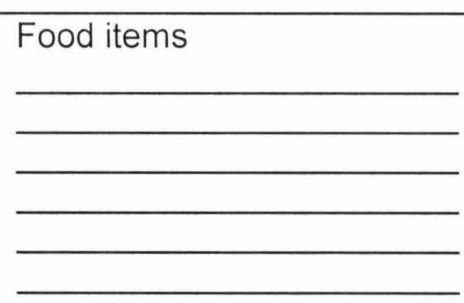

- General comments:

\section{Status of market/ marketing:}

1) Cash crops locally produced \& local prices:
- Potatoes
Rs./ kg
- Onions
$\mathrm{Rs} / \mathrm{Kg}$
- Carrot
Rs./ kg
- Apple
$\mathrm{Rs} . / \mathrm{kg}$

2) Marketing problems on cash crops export:

Constraint on export due to:

- High transport cost

- Un security of transport

- Storage problems

- Lower local prices 
3) What are the market price of the main items:

$\begin{array}{ll}\text { Wheat flour } & \text { Rs. } / \mathrm{kg} \\ \text { Rice } & \text { Rs./ kg } \\ \text { Beans } & \text { Rs. } / \mathrm{kg} \\ \text { Mong beans } & \text { Rs./ kg } \\ \text { Cooking oil } & \text { Rs./ kg } \\ \text { Beef (with bones) } & \text { Rs. } / \mathrm{kg} \\ \text { Mutton } & \text { Rs./ kg } \\ \text { Kerosene } & \text { Rs. } / \mathrm{kg} \\ \text { Benzene } & \text { Rs./ kg }\end{array}$

Surveyor overall comments list item wise:

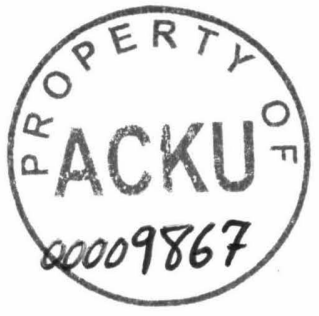

2.

3.

4 
